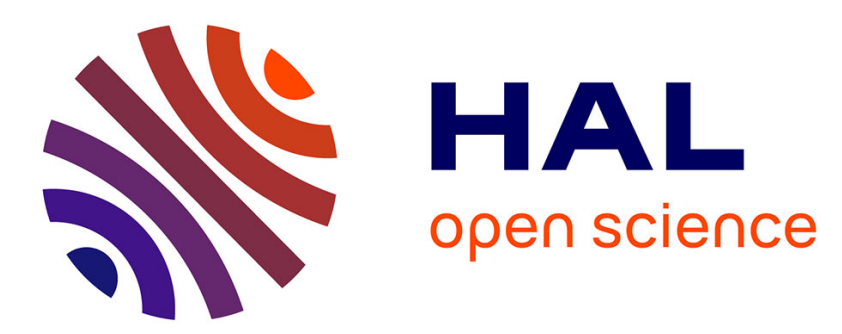

\title{
Effects of endosulfan on hepatoma cell adhesion: Epithelial-mesenchymal transition and anoikis resistance
} Ludovic Peyre, Nathalie Zucchini-Pascal, Georges de Sousa, Roger Rahmani

\section{To cite this version:}

Ludovic Peyre, Nathalie Zucchini-Pascal, Georges de Sousa, Roger Rahmani. Effects of endosulfan on hepatoma cell adhesion: Epithelial-mesenchymal transition and anoikis resistance. Toxicology, 2012, 300 (1-2), pp.19-30. 10.1016/j.tox.2012.05.008 . hal-01137000

\section{HAL Id: hal-01137000 \\ https://hal.science/hal-01137000}

Submitted on 30 Mar 2015

HAL is a multi-disciplinary open access archive for the deposit and dissemination of scientific research documents, whether they are published or not. The documents may come from teaching and research institutions in France or abroad, or from public or private research centers.
L'archive ouverte pluridisciplinaire HAL, est destinée au dépôt et à la diffusion de documents scientifiques de niveau recherche, publiés ou non, émanant des établissements d'enseignement et de recherche français ou étrangers, des laboratoires publics ou privés. 


\title{
Effects of endosulfan on hepatoma cell adhesion: Epithelial-mesenchymal transition and anoikis resistance
}

\author{
Ludovic Peyre, Nathalie Zucchini-Pascal*, Georges de Sousa, Roger Rahmani* \\ Laboratoire de Toxicologie Cellulaire et Moléculaire des Xénobiotiques, INRA, UMR 1331 TOXALIM Sophia Antipolis, 06903 Sophia Antipolis, France
}

\section{A R T I C L E I N F O}

\section{Article history:}

Received 28 March 2012

Received in revised form 10 May 2012

Accepted 12 May 2012

Available online 5 June 2012

\section{Keywords:}

Endosulfan

Anoikis

EMT

Hepatocarcinoma

HepG2

\begin{abstract}
A B S T R A C T
Endosulfan is an organochlorine pesticide commonly used in agriculture yet classified by the Stockholm Convention in 2011 as a persistent organic pollutant (POP). Its potential toxicity makes its continued use a major public health concern. Despite studies in laboratory animals, the molecular mechanisms underlying the carcinogenic effects of endosulfan in human liver remain poorly understood. In this study, we investigated the phenotypical effects of endosulfan on HepG2 liver cells. First, we found that endosulfan disrupted the anoikis process. Indeed, cells exposed to endosulfan were initially sensitized to anoikis and thereafter recovered their resistance to this process. This phenomenon occurred in parallel to the induction of the epithelial to mesenchymal (EMT) process, as demonstrated by: (1) reorganization of the actin cytoskeleton together with activation of the FAK signaling pathway; (2) repression of E-cadherin expression; (3) induction of Snail and Slug; (4) activation of the WNT/ $\beta$-catenin pathway; and (5) induction and reorganization of mesenchymal markers (S100a4, vimentin, fibronectin, MMP-7). Secondly, despite the acquisition of mesenchymal characteristics, HepG2 cells exposed to endosulfan failed to migrate. This incapacity to acquire a motile phenotype could be attributed to a disruption of the interaction between the ECM and the cells. Taken together, these results indicate that endosulfan profoundly alters the phenotype of liver cells by inducing cell detachment and partial EMT as well as disrupting the anoikis process. All these events account, at least in part, for the carcinogenic potential of endosulfan in liver.
\end{abstract}

(C) 2012 Elsevier Ireland Ltd. All rights reserved.

\section{Introduction}

Since the 1950s, organochlorine pesticides (OCPs) such as the chlorinated cyclodiene endosulfan have been employed extensively in agriculture, viticulture, horticulture, domestic and public health. Endosulfan is sold under different trade names (Thiodan ${ }^{\circledR}$, Rocky $^{\circledR}$, Thionex ${ }^{\circledR} \ldots$ ) and corresponds to a mixture of $70 \%$ endosulfan- $\alpha$ and $30 \%$ endosulfan- $\beta$. While it does have beneficial effects on crops, it also represents a potential source of environmental contamination and risk to public health (Silva and Gammon,

Abbreviations: Ab, antibody; DAPI, 4',6'-di-amidino-2-phenyl indole; DMSO, dimethyl sulfoxide; ECM, extracellular matrix; EMT, epithelial to mesenchymal transition; FAK, focal adhesion kinase; FBS, foetal bovine serum; HCC, hepatocellular carcinoma; LEF1/TCF-1, lymphoid enhancer factor $1 / \mathrm{T}$ cell factor 1 ; MMP, metalloprotease; MTT, 3-(4,5-dimethylthiazol-2-Yl)-2,5-diphenyltetrazolium bromide; Poly-HEMA, poly 2-hydroxyethyl methacrylate; POP, persistent organic pollutant; ROCK, Rho-associated protein kinase; WNT, wingless integration site; XIAP, X-linked inhibitor of apoptosis protein.

* Corresponding authors at: Laboratoire de Toxicologie Cellulaire et Moléculaire des Xénobiotiques, INRA, UMR 1331, 400 route des Chappes, BP167, 06903 Sophia Antipolis, France. Tel.: +334923865 48; fax: +33492386401.

E-mail addresses: zucchini@sophia.inra.fr (N. Zucchini-Pascal), rahmani@sophia.inra.fr (R. Rahmani).
2009). Indeed, endosulfan is a persistent organic pollutant (POP) that can build up in the environment and bioaccumulate through the food chain. Its persistent and bioaccumulative properties enable it to become stored in fats where it persists for a long time. Endosulfan is readily absorbed by humans via the stomach, the skin, the lungs, and the placenta (Lopez-Espinosa et al., 2008). This OCP is one of the most toxic pesticides currently on the market and is responsible for a large number of poisoning-related deaths (Moses and Peter, 2010). In animals, it is toxic to the liver, kidney, nervous system, blood system, immune system and reproductive organs (Hashizume et al., 2010; Karatas et al., 2006; Ahmed et al., 2011; Merhi et al., 2010; Briz et al., 2011; Chan et al., 2006; Choudhary et al., 2003; Aggarwal et al., 2008). Due to the risk of adverse effects on human health, the World Health Organization (WHO) classified endosulfan as a moderately hazardous Class 2 pesticide while the Environmental Protection Agency (EPA) considered it as "highly acutely toxic" (Category I). Despite then being banned in more than 62 countries and by the Stockholm Convention in 2011, it is still used extensively (Weber et al., 2010). An interdiction for use will be effective in 2017.

While the potential carcinogenic effects of endosulfan remain a matter of debate, in vitro studies have revealed mechanisms induced by endosulfan that are implicated in tumor development and progression in testes, breast and liver (Hardell and Eriksson, 
Table 1

Primary antibodies used for Western blot and immunofluorescence staining.

\begin{tabular}{|c|c|c|c|c|c|}
\hline Antigen & Phosphorylation site & Source/type & Manufacturer & Dilution WB & Dilution IF \\
\hline ROCK1 & & Rabbit mAba & Epitomics & $1: 2000$ & $1: 200$ \\
\hline pFAK & Tyr925 & Rabbit pAb ${ }^{\mathrm{b}}$ & Cell signaling & $1: 2000$ & \\
\hline FAK & & Rabbit pAb & Cell signaling & $1: 2000$ & \\
\hline Vimentin & & Rabbit mAb & Epitomics & & $1: 200$ \\
\hline TCF1/LEF-1a & & Rabbit mAb & Epitomics & $1: 10,000$ & \\
\hline Gapdh & & Rabbit mAb & Cell signaling & $1: 15,000$ & \\
\hline E-cadherin & & Rabbit mAb & Epitomics & $1: 5000$ & \\
\hline$\beta$-Catenin & & Rabbit mAb & Santa Cruz & $1: 2000$ & $1: 400$ \\
\hline Fibronectin & & Rabbit mAb & Epitomics & $1: 1000$ & $1: 100$ \\
\hline Snail & & Rabbit pAb & Santa Cruz & & $1: 200$ \\
\hline Slug & & Rabbit mAb & Cell signaling & & $1: 300$ \\
\hline
\end{tabular}

a mAb, monoclonal antibody.

b pAb, polyclonal antibody.

2003; Høyer et al., 2002; Fransson-Steen et al., 1992; Perez-Carreon et al., 2009). An example of such a mechanism is the disruption of gap junctions (Ruch et al., 1990). Such gap junctional intercellular communication uncouplers are responsible for many cellular dysfunctions and multiple diseases including cancer (Ehrlich et al., 2006; Trosko, 2011). In addition, the genotoxic potential of endosulfan has been described in HepG2 cells (Hashizume et al., 2010; Li et al., 2011) and exposure to sub-lethal doses of endosulfan and its metabolites causes DNA damage and mutations (Antherieu et al., 2007; Bajpayee et al., 2006). One study using a computational quantum chemical model indicated that endosulfan and all its metabolites have carcinogenic potential (Bedor et al., 2010). However, the exact molecular mechanisms underlying the toxic and carcinogenic effects of endosulfan in liver cells remain poorly understood.

Epithelial to mesenchymal transition (EMT) is a highly coordinated multistep process during which epithelial cells acquire mesenchymal fibroblast-like properties. It has been implicated in a variety of diseases including fibrosis and in the progression of carcinoma (Jou and Diehl, 2010). This fundamental program also plays a key role in the critical phases of embryonic development and in adults it contributes on the one hand to physiological processes such as tissue repair and on the other pathological conditions (Kalluri and Weinberg, 2009). The morphological changes imposed are governed by multiple molecular mechanisms including the loss of epithelial proteins such as E-cadherin (Cavallaro and Christofori, 2004; Huber et al., 2005) that leads to the reduction in cell-to-cell junctions (adherens and gap junctions), the loss of cell polarity, and the gain of mesenchymal markers such as the extracellular matrix compound fibronectin, the intermediate filament protein vimentin and S100a4 (Peinado et al., 2004; Kim et al., 2011; Ogunwobi and Liu, 2011). All these steps lead to the acquisition of motile and invasive properties (Matsuo et al., 2009).

E-cadherin is thought to be downregulated via several repressors acting either indirectly (e.g. Twist, Goosecoid) or directly by binding to and repressing the E-cadherin promoter (e.g. Snail, Slug, Zeb) (Peinado et al., 2007; Yang and Weinberg, 2008). Ecadherin repression is frequently accompanied by the activation of the $\beta$-catenin/Wnt signaling cascade (Fransvea et al., 2008; van Zijl et al., 2009a,b). Indeed, during EMT, the cytoplasmic stabilization of $\beta$-catenin occurring via WNT activation signaling and GSK3- $\beta$ repression (Medici et al., 2008), leads to the formation of a nuclear complex TCF/LEF/ $\beta$-catenin that modulates the expression of target genes such as fibronectin, MMP7 or S100a4 (Iwai et al., 2010). Communications between cells and the new extracellular matrix environment are mainly mediated by the activation of the focal adhesion kinase-FAK-transduction pathway (Chatzizacharias et al., 2008; Cicchini et al., 2008).

The liver is the most sensitive tissue to xenobiotic exposure and constitutes the main target of endosulfan toxicity. Thus, we investigated the cellular and molecular effects of endosulfan in human liver cells using the HepG2 cell line. These cells retain many cellular functions allowing the study of several molecular processes among which cell plasticity and anoikis (Roe et al., 1993). In this study, we show that endosulfan permits a transient anoikis induction that is followed by recovery of anoikis resistance. This process occurs in parallel to partial EMT and is characterized by the repression of E-cadherin expression, the loss of adherent junctions, cytoskeleton reorganization, extra-cellular matrix (ECM) reshuffle, $\mathrm{WNT} / \beta$-catenin pathway activation and the gain of mesenchymal markers (vimentin, fibronectin, S100a4). Despite evidence of all these events, the cells remain unable to acquire a motile phenotype. Thus the present study shows that endosulfan transiently sensitizes HepG2 cells to anoikis before allowing a later recovery of resistance to this process that coincides with the induction of partial EMT. Such events could account, at least in part, for the carcinogenic potential of endosulfan.

\section{Materials and methods}

\subsection{Materials}

The human hepatocellular carcinoma cells HepG2 were obtained from ATCC (American Type Culture Collection, Manassas, VA). Dulbecco's modified Eagle's medium (DMEM), fetal bovine serum (FBS), penicillin/streptomycin solution, sodium pyruvate and Eagle's non-essential amino acids were from BioWhittaker (Cambrex Company, Walkersville, USA). DMSO (dimethylsulfoxide) and chemicals were from Sigma-Aldrich (L'Isle d'Abeau Chesne, Saint Quentin Fallavier, France). Protein assay materials were from Bio-Rad. All fluorescence reagents were from Molecular Probes (Eugene, OR). The OC endosulfan was from ChemService (West Chester, PA). The antibodies used for western blotting and immunodetection experiments were from Cell Signaling, Santa Cruz and Epitomics (Table 1). Cells were visualized with a Nikon Eclipse TE2000 phase contrast microscope.

\subsection{Cell culture and drug treatments}

HepG2 cells were maintained in DMEM with $1 \%$ penicillin/streptomycin, $1 \%$ non essential amino acids, sodium pyruvate, and 10\% FBS, in humidified atmosphere at $37{ }^{\circ} \mathrm{C}$ containing $95 \% \mathrm{O}_{2}$ and $5 \% \mathrm{CO}_{2}$. After washing with sterile phosphate buffer saline (PBS), cells were detached by trypsinization (trypsin/EDTA) and plated at a concentration of $0.5-1 \times 10^{6}$ or $0.4-0.5 \times 10^{5}$ cells $/ \mathrm{ml}$ in 6 -well or 24 -well plates respectively, depending on the experiment. For all experimental conditions, FBS was reduced to 5\% in DMEM medium and cells were treated for the indicated time with endosulfan prepared as dimethylsulfoxide (DMSO) stock solution. The final DMSO concentration was $0.25 \%(\mathrm{v} / \mathrm{v})$.

\subsection{Viability test}

Viable cells were determined by measuring the conversion of the tetrazolium salt MTT 3-(4,5-dimethylthiazol-2-yl)-2,5-diphenyltetrazolium bromide Sigma-Aldrich (St.Louis, MO) to formazan, as previously described (Fautrel et al. 1991). Briefly, cells were seeded in 96 well plates and treated at $50 \%$ confluency with a concentration of $20 \mu \mathrm{M}$ endosulfan during 24,48 and $72 \mathrm{~h}$. The cells were then incubated with $0.5 \mathrm{mg} / \mathrm{ml}$ MTT for $2 \mathrm{~h}$ at $37^{\circ} \mathrm{C}$. The water-insoluble formazan crystal was dissolved by adding $100 \mu \mathrm{l}$ DMSO to each well and the absorbance was determined with a spectrophotometer at $550 \mathrm{~nm}$ (MR7000, Dynatech Laboratories, Inc., USA). 


\subsection{Real-time cellular impedance}

The xCELLigence system was used according to the manufacturers' instructions (Roche Applied Science, Mannheim, Germany) and ACEA Biosciences (San Diego CA, USA). Briefly, $1 \times 10^{4}$ cells were added to the 96-well E-plates. Twenty-four hours later, cells were treated with different concentrations of endosulfan $(2,10$ $20,50,100$ and $200 \mu \mathrm{M}$ ) in 5\% FBS DMEM medium. Real-time cellular impedance was measured in each well (cell index values) and a signal was observed through the integrated software (RTCA Analyzer). Each curve is representative of an experiment performed in triplicate. To compare the influence of the endosulfan on the cells, the normalized cell index ( $\mathrm{NCI}$ ) was used, calculated using the DMSO control condition.

\subsection{Immunofluorescence}

Cells were seeded on glass slides in 24 -well plates $\left(4 \times 10^{5}\right.$ cells per well) and were exposed to endosulfan at the indicated time and concentration. For cytoskeleton and extra-cellular matrix proteins (Rho-associated kinase, vimentin and fibronectin) and transcription factors (Snail, Slug and Hif-1 $\alpha$ ), the cells were fixed with $4 \%$ paraformaldehyde (PFA) and permeabilized in $0.5 \%$ saponin. For structural proteins (E-cadherin and $\beta$-catenin), cells were fixed in $-20^{\circ} \mathrm{C}$ methanol and permeabilized in $0.25 \%$ triton. In both cases, slides were incubated with antibodies (Table 1 ) for $1 \mathrm{~h}$ at room temperature. After washing with PBS, goat anti-rabbit or anti-mouse IgG coupled to AlexaFluor ${ }^{\circledR} 488$ or 594 (Molecular Probes, Eugen, OR) were added to slides, before incubation in a dark room for $1 \mathrm{~h}$ at room temperature. The actin cytoskeleton was observed after incubation with phalloidin coupled with AlexaFluor 488 for $5 \mathrm{~min}$, and the nucleus after incubation with DAPI $1 \mu \mathrm{g} / \mathrm{ml}$ (2,6-diamidino-2-phenylindone) for $10 \mathrm{~min}$. Slides were mounted and sealed in ProLong Gold antifade reagent (Invitrogen). Observations were performed with an inverted fluorescence microscope (Nikon) equipped with a CDD camera (ORCA-ER Hamamatsu Photonics).

\subsection{Detection of the anoikis process}

The cells were treated for 48 or $72 \mathrm{~h}$ with $2,10,20,50$ and $100 \mu \mathrm{M}$ of endosulfan. Then, the culture media containing floating cells were collected, centrifuged, and pellets reseeded into new 6-well plates with DMEM supplemented with 5\% FBS. This protocol is designed to test the ability of cells to adhere in the absence of endosulfan. Eighteen days later, the MTT viability test was performed to estimate the number of non-adhering cells from the observed population of adhering cells.

Secondly, to determine the level of anoikis, $2 \times 10^{5}$ cells were cultured as a suspension on plates coated with (poly(2-hydroxyethyl methacrylate) (poly-HEMA) (Sigma) for the indicated periods of time. Apoptotic cells were then estimated by enzymatic assay using caspase- 3 activity as a marker of apoptosis.

\subsection{Enzymatic assays for caspase activity}

Caspase activity was assessed by measuring fluorophore (7-amido-4trifluoromethylcoumarin $(A F C)$ ) release from caspase tetrapeptide substrate $\mathrm{N}$-acetyl-Asp-Glu-Val-Asp (Ac-DEVD) for caspases-3-like activity. Briefly, cells grown in 6-well culture dishes were scraped into ice-cold hypotonic buffer. Cells were then lysed by being subjected to three cycles of freezing and thawing. Protein concentrations were determined using the BCA Protein Assay kit (Pierce, Rockford, IL, USA) and equal amounts were mixed with buffer B (312.5 mM HEPES, pH 7.5, $31.25 \%$ sucrose, $0.3125 \%$ CHAPS, $50 \mu \mathrm{M}$ of relative substrate enzymes). The fluorometric assay detected the shift in AFC fluorescence emission following cleavage from tetrapeptide-AFC, as measured in a fluorometer $\left(\lambda_{\mathrm{ex}}=390 \mathrm{~nm} ; \lambda_{\mathrm{em}}=530 \mathrm{~nm}\right)$.

\subsection{Western blot}

HepG2 cells were scraped into hypotonic buffer (20 mM HEPES, pH 7.5, $10 \mathrm{mM}$ $\mathrm{KCl}, 15 \mathrm{mM} \mathrm{MgCL} 2,0.25 \mathrm{mM}$ sucrose, $1 \mathrm{mM}$ EDTA, $1 \mathrm{mM}$ EGTA, $1 \mathrm{mM}$ DTT, $0.1 \mathrm{mM}$ PMSF, $10 \mu \mathrm{g} / \mathrm{ml}$ pepstatin A, $10 \mu \mathrm{g} / \mathrm{ml}$ leupeptin, and the phosphatase inhibitory cocktail PhosphoSTOP, Roche). The protein concentration in each cell lysate was quantified using a BCA Protein Assay Kit (Pierce), with bovine serum albumin (BSA) used as a standard. Equal protein amounts were separated by SDS-polyacrylamide gel electrophoresis on $10 \%$ gels and were transferred to PVDF membranes. The membranes were immunoblotted with antibodies (Table 1 ) for $1 \mathrm{~h}$ at room temperature or overnight at $4{ }^{\circ} \mathrm{C}$. After washing, membranes were then incubated with horseradish peroxidase-conjugated secondary antibodies (anti-mouse or antirabbit immunoglobulin G; Promega, Madison, WI, USA) for $1 \mathrm{~h}$ at room temperature. After washing, the signals were detected using Immobilon Western Detection Reagents (Millipore, Molsheim, France) and acquired using a CCD camera (ChemiGenius2, SynGene).

\subsection{Reverse transcription-quantitative polymerase chain reaction}

Total RNA was isolated using acid phenol extraction. One microgram of total RNA was reverse transcribed using a kit (SuperScript II; Invitrogen Corp., Carlsbad, California) following the manufacturer's instructions. Quantitative PCR analysis was carried out with LightCycler ${ }^{\circledR} 480$ Probes Master (Roche), according to the manufacturer's instructions, together with FAM-labeled hydrolysis probes from the Universal Human Probe Library Set (Roche). Intron-spanning primers were designed using the Universal Probe Library Assay Design Center software. Calculations were made using gapdh as the endogenous control reference gene. Fold differences in gene expression were calculated using the LightCycler software, taking into account the efficiency of amplification as determined from a standard curve obtained with the second-derivative maximum method.

\subsection{Cell migration assay}

At $90 \%$ confluence HepG 2 cells were trypsined and $3 \times 10^{6}$ of cells per well were added to a 6 well plate. After $24 \mathrm{~h}$ of incubation, the confluent tissue formed was scratched 4 times per well with a sterile pipette tip. Cells were washed twice with PBS medium before being treated with $0.25 \%$ DMSO or $20 \mu \mathrm{M}$ endosulfan in a DMEM medium depleted with 5\% FBS. Images were taken immediately $(0 \mathrm{~h})$ with an inverted fluorescence microscope (Nikon) equipped with a CDD camera (ORCAER Hamamatsu Photonics) and NIS-Elements AR 2.30 software at $4 \times$ magnification. $24 \mathrm{~h}$ later, the cell migration progress was photographed in the same conditions and all data were treated with the TScratch software tool developed for automated analysis of monolayer wound healing assays as described by Gebäck et al. (2009).

\subsection{Statistical analysis}

Each experiment was repeated at least three times. Data shown are an average \pm standard deviation (SD). Statistical analysis of in vitro studies was performed using a Student's $t$ test. Levels of probability are indicated as ${ }^{*} P<0.05$ or ${ }^{* *} P<0.01$.

\section{Results}

\subsection{Morphological changes in HepG2 cells after endosulfan treatment}

To assess the effect of endosulfan on hepatoma cells, HepG2 cells were treated with increasing concentrations of the organochlorine pesticide. Viability was evaluated by MTT dye reduction assay after 24,48 and $72 \mathrm{~h}$ of treatment or by measuring cellular impedance in real-time. As shown in Fig. 1, endosulfan decreased HepG2 viability in a dose- and time-dependent manner. Cytotoxicity occurred within $72 \mathrm{~h}$ following $50 \mu \mathrm{M}$ endosulfan and peaked after $100 \mu \mathrm{M}$ $\left(\mathrm{IC}_{50}=68.9 \mu \mathrm{M}\right.$ after $72 \mathrm{~h}$ treatment $)$.

Results obtained with the xCELLigence system do not allow the determination of IC50 values. Indeed, this technology is a noninvasive cytotoxicity assay that is based on the measurement of impedance in real time (cell index values). This parameter reflects the cellular status with regards to such as cell proliferation, variations in cell membrane integrity, cytotoxicity, cell adhesion and spreading, and cell migration. Fig. 1B depicts the dynamic changes in cell index $(\mathrm{CI})$ values of cells after exposure to different concentrations of endosulfan. At 100 and $200 \mu \mathrm{M}$, endosulfan lead to a slight decline in the cell survival rate but failed to induce $100 \%$ mortality. At lower concentrations, a significant increase in the slope corresponding to the evolution of cell index over time was observed (Fig. 1B and C). This phenomenon could be explained by morphological changes correlating with defects in cell adhesion or migration.

In the control condition (DMSO), HepG2 cells had an epithelial cell-like morphology with a characteristic "cobblestone" appearance and organized cortical pattern of F-actin at cell-to-cell junctions (Fig. 1D). By contrast, HepG2 cells exposed to $20 \mu \mathrm{M}$ endosulfan treatment exhibited more poorly defined intercellular borders and were more often spherical and individualized (arrows). These modifications correlated with the reduced organization of F-actin into a cortical pattern at cell-to-cell junctions (Fig. 1D, arrowhead).

These results suggested that endosulfan is toxic at high concentrations $(>50 \mu \mathrm{M})$ but that lower doses could nevertheless induce phenotypic modifications. 


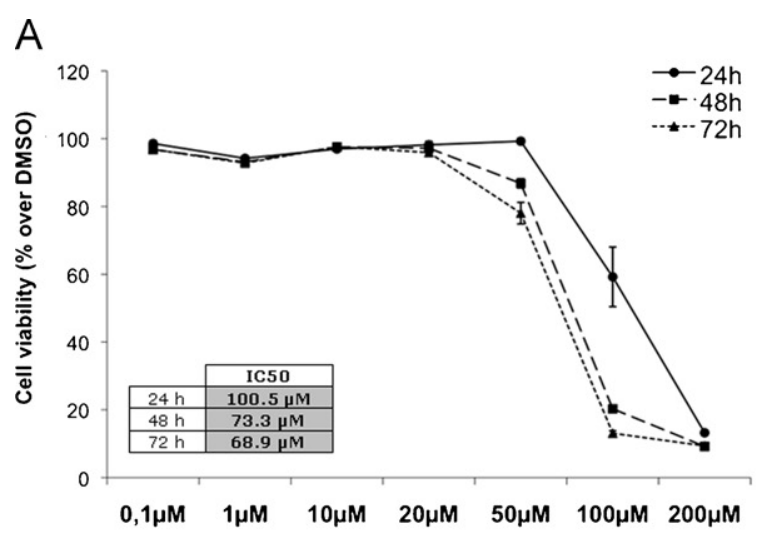

C

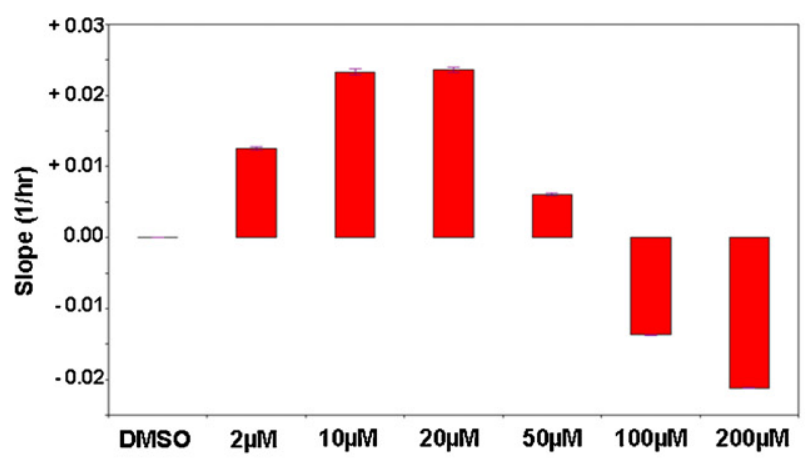

$\mathrm{B}$

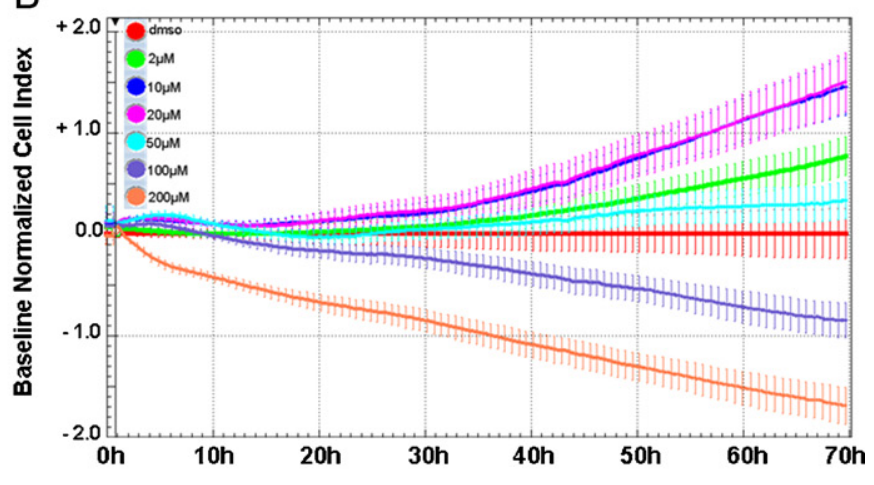

D
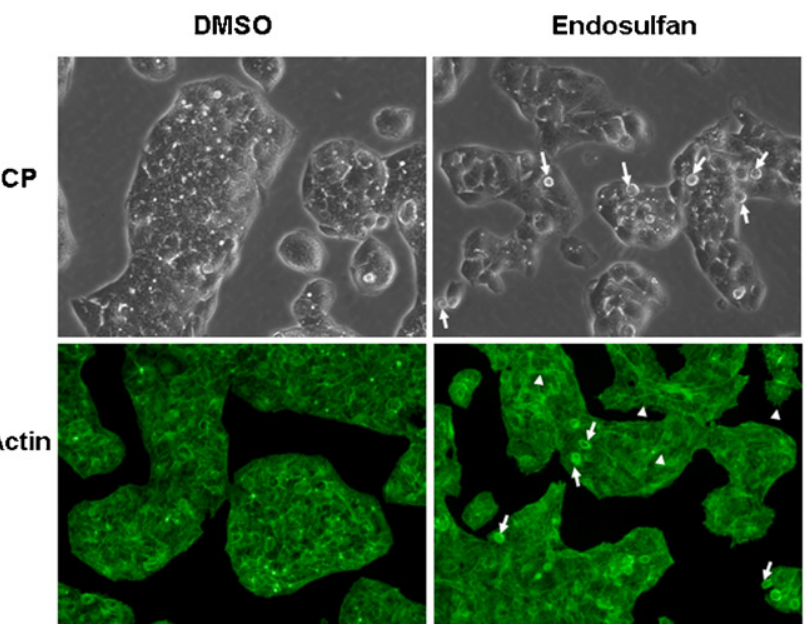

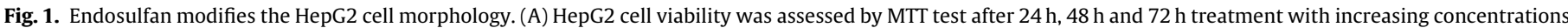

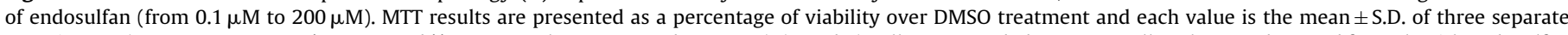

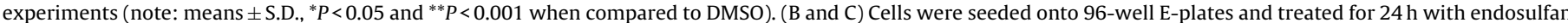

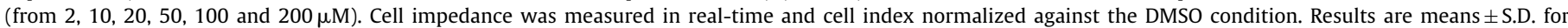

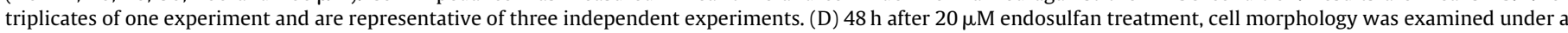

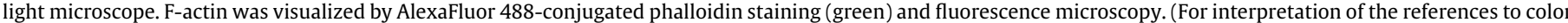
in this figure legend, the reader is referred to the web version of the article.)

\subsection{Endosulfan sensitizes HepG2 cells to anoikis}

Based upon our morphological findings, we sought to evaluate whether endosulfan affected cell death processes. We observed that nuclei from individualized cells after exposure to 20 and $50 \mu \mathrm{M}$ endosulfan were condensed and fragmented, as shown by DAPI staining (Fig. 2A). Moreover, when these floating cells were replated in tissue culture dishes after $48 \mathrm{~h}$ or $72 \mathrm{~h}$ in suspension, they displayed the ability to attach and proliferate (Fig. 2B). Indeed, 18 days after having replated the cells, MTT test showed that the floating cells obtained after endosulfan treatment $(<50 \mu \mathrm{M})$ had grown in a time- and dose-dependent manner. However, at high concentrations ( 50 and $100 \mu \mathrm{M}$ ), the number of living floating cells seemed to be too low, as demonstrated by the low viability rate obtained after replating (Fig. 2C). Hence, these results suggest that the process leading to their individualization is reversible. We firstly investigated the effect of endosulfan on capase-3 activity levels (as a marker of apoptosis) in both the adherent and the floating cells after $48 \mathrm{~h}$ endosulfan treatment (Fig. 3A). The caspase-3 activity remained stable in the HepG2 cells of the monolayer, whereas it increased significantly in the floating cells at concentrations $\geq 10 \mu \mathrm{M}$ (400-450\% of activation/DMSO). Secondly, to investigate whether prevention of attachment was the main cause of cell death induced by endosulfan, HepG2 cells were cultured on polyHEMA (+poly-HEMA), which prevented cells from attaching. The cells responded with a significant induction of caspase- 3 activity when exposed to 20 or $50 \mu \mathrm{M}$ endosulfan for $4 \mathrm{~h}$ and $24 \mathrm{~h}$, but not with DMSO or when kept under adherent conditions (-polyHEMA). However, this increased caspase- 3 activity seemed to be transient, as it was not observed after $48 \mathrm{~h}$ treatment (data not shown). Moreover, after $24 \mathrm{~h}$ endosulfan treatment $(20 \mu \mathrm{M})$ we observed an induction of the gene encoding X-linked inhibitor of apoptosis (XIAP), the endogenous caspase- 3 and -7 inhibitor. Thus, endosulfan initially sensitized the HepG2 cells to anoikis yet permitted the restoration of intrinsic anoikis resistance later on.

Taken together, these findings demonstrate that endosulfan may induce anoikis in HepG2 cells, probably via disruption of cell attachment.

\subsection{Endosulfan induces changes in the cytoskeleton and ECM associated with the activation of FAK signaling and potential destabilization of adherent junctions}

We therefore investigated whether endosulfan can perturb cellular adhesion by studying changes in the expression of proteins implicated in the modification of the actin cytoskeleton of HepG2 cells exposed to endosulfan. We examined the localization and expression of the Rho-associated kinase (ROCK1), a well-known effector of the RhoGTPAses implicated in lamelliopodia and stress fiber formation during cytoskeleton remodeling (Schaller, 2010). 


\section{Endosulfan}
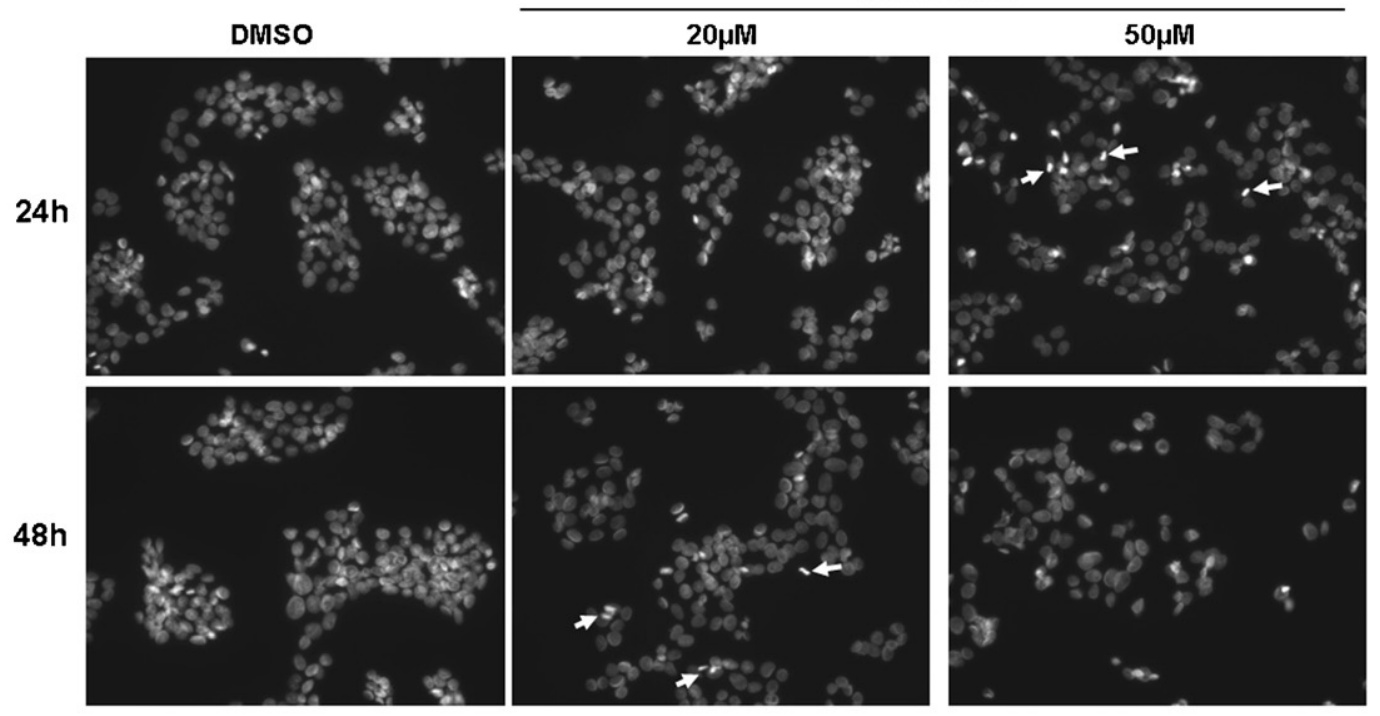

B

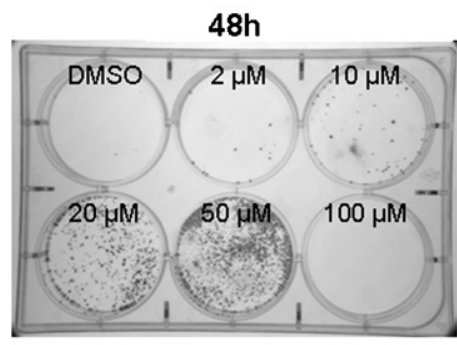

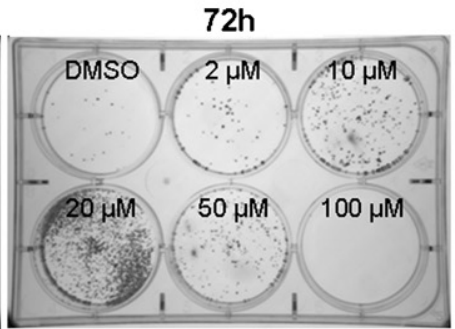

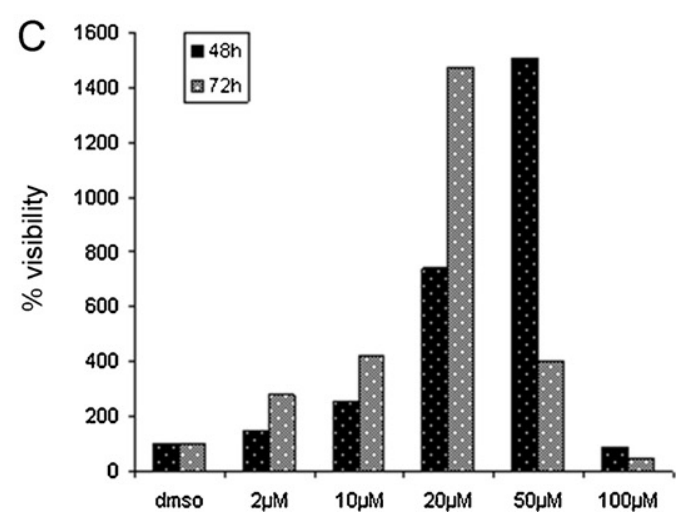

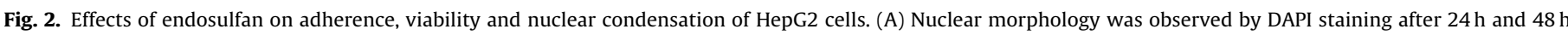

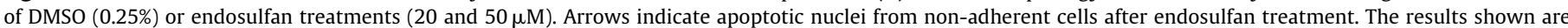

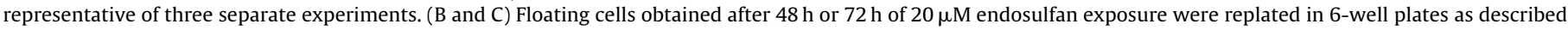
in the material and methods section. 18 days after plating, pictures were taken (B) and cell viability was measured by MTT test (C).

As demonstrated by immunofluorescence (Fig. 4A), the cellular localization of ROCK1 was modified after $48 \mathrm{~h}$ of treatment with $20 \mu \mathrm{M}$ endosulfan. Indeed, in the control condition (DMSO), ROCK1 was mainly colocalized with actin leading to a cortical pattern at cell-to-cell junctions, whereas in the presence of endosulfan, this protein was distributed uniquely throughout the cytoplasm. We also examined the protein levels of ROCK1 by western blot analysis. After endosulfan treatment, the expression of this protein was up-regulated in a time-dependent manner (Fig. 4B).

Focal adhesion kinase (FAK) signaling was also implicated in the control of the actin cytoskeleton organization. Indeed, FAK mediates cells motility and adhesion turnover through regulation of the RhoGTPases and ROCK activity (Riento and Ridley, 2003). We found that endosulfan increased the phosphorylation of FAK at Tyr 925 in a time-dependent manner as soon as $8 \mathrm{~h}$ of endosulfan treatment (Fig. 4C). The phosphorylation of the Tyr-925 residue leads to cell migration and cell protrusion (Deramaudt et al., 2011).

Extracellular matrix (ECM) remodeling is a major phenotypic modification observed during cell motility and migration. Fibronectin, a high-molecular weight glycoprotein, serves as a scaffold for the fibrillar ECM. We therefore analyzed fibronectin levels by western blotting and immunofluorescence studies. Immunofluorescence analysis showed an important increase of fibronectin in the cytoplasm of HepG2 cells after $48 \mathrm{~h}$ of endosulfan treatment (Fig. 4D). These findings are consistent with the up-regulation of fibronectin detected by western blot (Fig. 4E). It is worth noting that the protein level of fibronectin was increased after $30 \mathrm{~min}$ of endosulfan treatment and peaked after about $60 \mathrm{~min}$. Moreover, fibronectin was deposited as fibrils (Fig. 4F) in the extracellular compartment, $48 \mathrm{~h}$ after endosulfan exposure. Interestingly, endosulfan did not increase the gene expression of Itga5, corresponding to the $\alpha 5$ chain of the fibronectin receptor integrin $\alpha 5 \beta 1$ (data not shown). This integrin is the main receptor of fibronectin allowing cells to migrate.

Together, these results show that endosulfan induced cytoskeleton remodeling and a modification of the ECM composition.

\subsection{Loss of adherent junctions through E-cadherin repression: possible involvement of the repressors Snail and Slug}

To further confirm the effect of endosulfan on cell adhesion, we investigated E-cadherin gene and protein expression levels in HepG2 cells exposed to endosulfan. Endosulfan significantly decreased the protein levels of E-cadherin after $24 \mathrm{~h}$ and $72 \mathrm{~h}$ of endosulfan treatment (Fig. 5A). Moreover, E-cadherin mRNA expression was decreased by approximately $50 \%$ after $48 \mathrm{~h}$ endosulfan treatment (Fig. 5B). These data suggested that E-cadherin expression is repressed in HepG2 cells at the transcriptional level after endosulfan exposure. Hence, we sought to determine the expression and the localization of Snail and Slug, two direct 


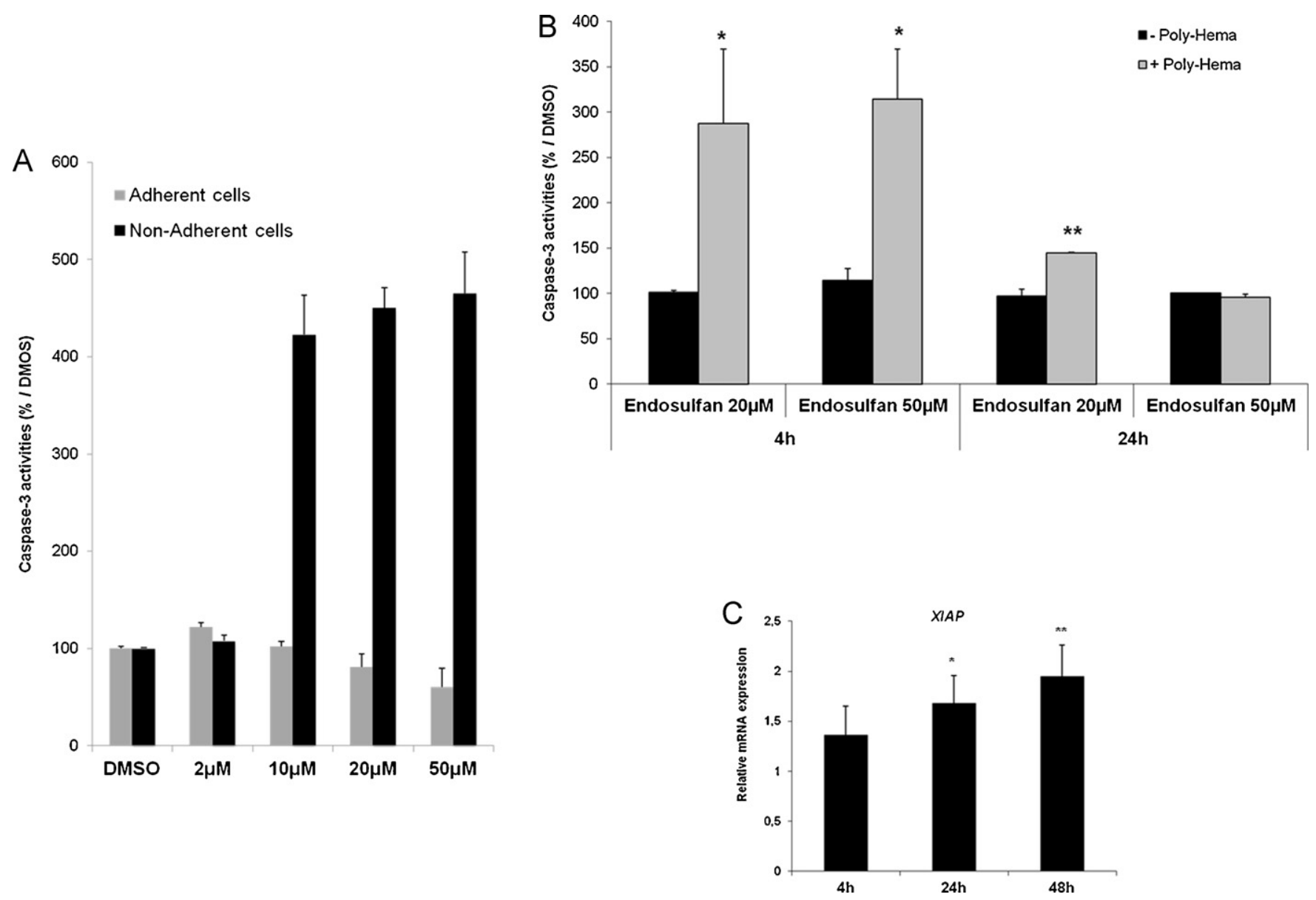

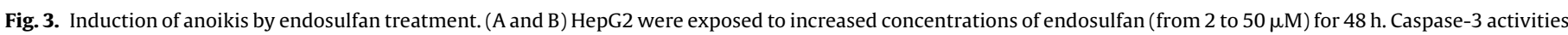

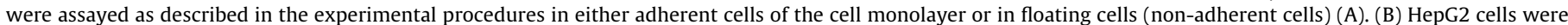

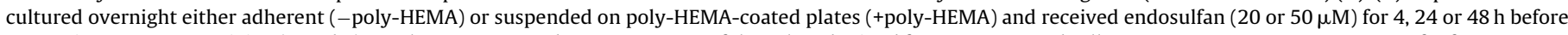

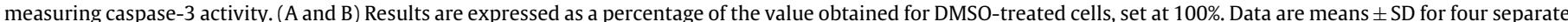

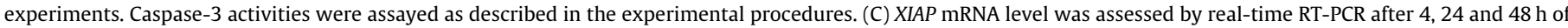

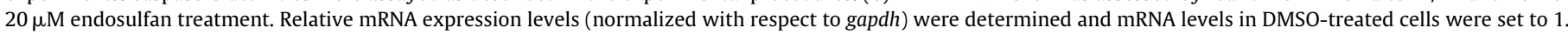
Error bars indicate the means \pm SEM of triplicate determinations from three independent experiments. Note: ${ }^{*} P>05$ and ${ }^{* *} P>0.01$.

repressors of E-cadherin transcription. We found that endosulfan increased Slug and Snail mRNA after $24 \mathrm{~h}$ and $48 \mathrm{~h}$, respectively (Fig. 5C). Concomitantly, we observed a nuclear translocation of these two factors into the nucleus of HepG2 cells treated with endosulfan (Fig. 5D).

Since a decrease in levels of E-cadherin is a widely accepted characteristic associated with EMT, we wondered whether endosulfan could activate this process.

\subsection{Endosulfan induces stabilization and nuclear translocation of $\beta$-catenin}

During EMT, loss of E-cadherin-mediated cell-cell adhesion destabilizes the $\beta$-catenin interaction with actin cytoskeleton and can promote its activation. Accordingly, we sought to evaluate whether endosulfan could act on the $\beta$-catenin signaling pathway (Clevers, 2006).

After endosulfan treatment, the protein level of $\beta$-catenin increased in a time-dependent manner (Fig. 6A) without significant modulation of its gene expression (Fig. 6B). This protein stabilization occurred together with the nuclear translocation of $\beta$-catenin after $48 \mathrm{~h}$ endosulfan treatment, as shown by immunofluorescence imaging in Fig. 6C. Once in the nucleus, $\beta$-catenin binds with transcription factors, such as LEF/TCF, to activate different targets genes, such as LEF1, TCF-1, MMP-7 or CCND1 (cyclin-D1) (Roose and
Clevers, 1999; Wielenga et al., 1999; Brabletz et al., 1999; Tetsu and McCormick, 1999). Endosulfan increased in a time-dependent manner the protein level of LEF1/TCF-1 when compared to the DMSO condition (Fig. 6D). Moreover, we found that endosulfan up-regulated both MMP-7 and CCND1 at the mRNA level after $48 \mathrm{~h}$ treatment.

These results suggest that endosulfan activates the $W N T / \beta$ catenin signaling pathway.

\subsection{Endosulfan induces gain of the mesenchymal markers S100a4 and vimentin but does not confer the ability to migrate}

EMT is characterized by loss of epithelial and gain of mesenchymal markers. Consequently, we investigated the effect of endosulfan on the expression of S100a4, a marker of hepatocytes undergoing EMT, and vimentin, an intermediate filament protein normally found in cells of mesenchymal origin.

As demonstrated by real-time PCR, endosulfan increased transiently S100a4 gene expression, as soon as $4 \mathrm{~h}$ and peaked after $24 \mathrm{~h}$ endosulfan treatment (Fig. 7A). Moreover, we observed increased amounts of vimentin in the cytoplasm of HepG2 cells exposed to endosulfan (Fig. 7B).

These results would suggest that endosulfan leads to a conversion of HepG2 cells to a mesenchymal phenotype with the capacity to migrate. Yet, wound-healing assays revealed no 
A

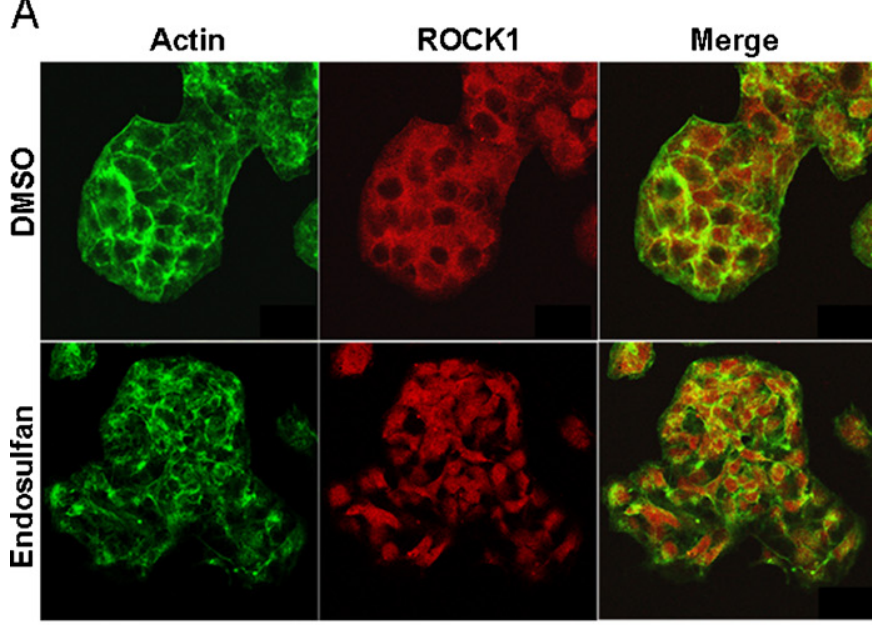

B

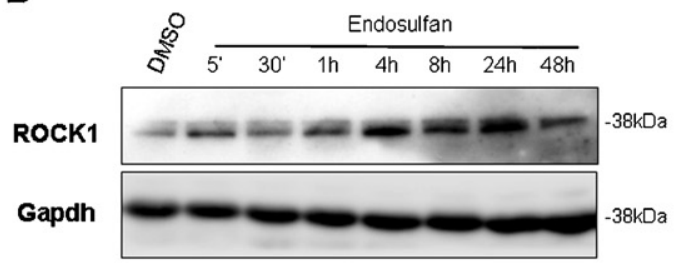

C

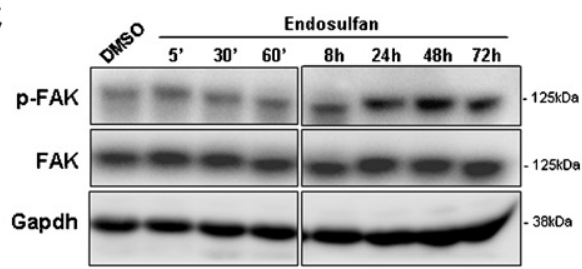

$\mathrm{F}$

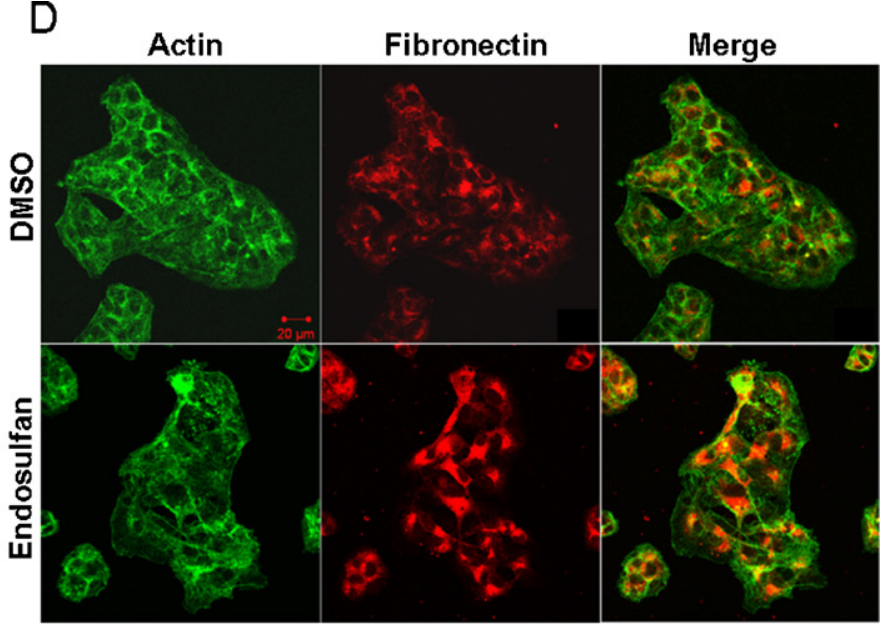

$E$
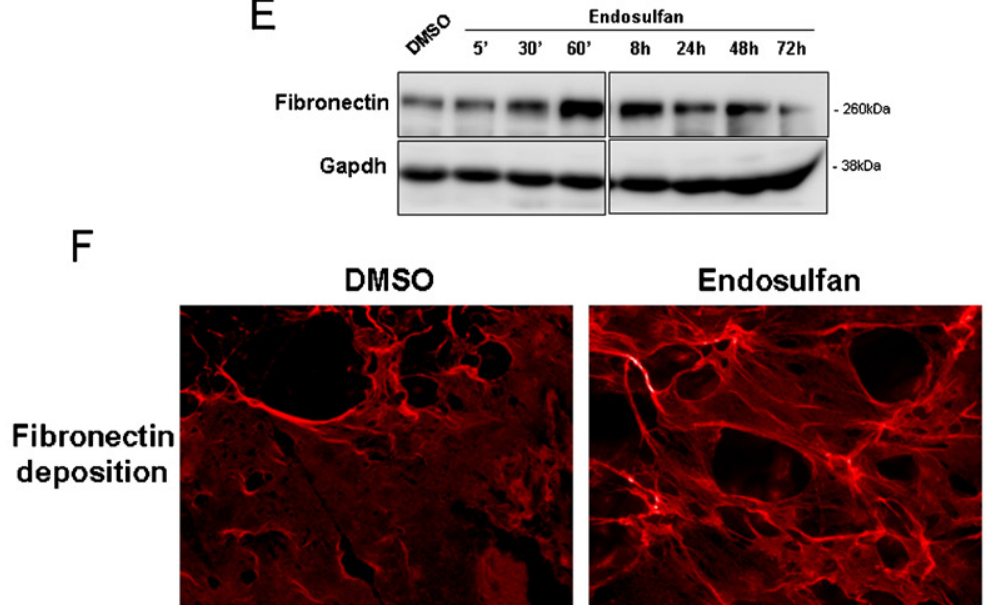

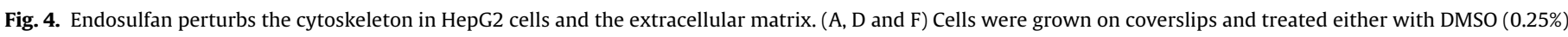

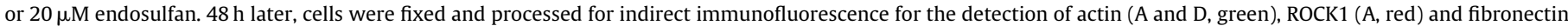

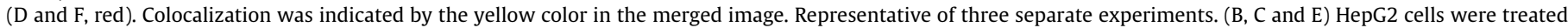

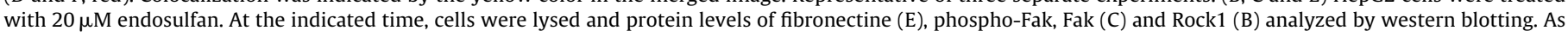

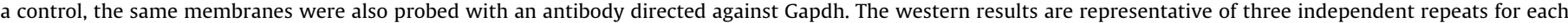
experiment. (For interpretation of the references to color in this figure legend, the reader is referred to the web version of the article.)

significant increase in wound closure after $24 \mathrm{~h}$ or $48 \mathrm{~h}$ endosulfan treatment when compared to the DMSO condition (Fig. 7C).

Thus although endosulfan is able to induce major changes with regards to the expression of epithelial characteristics, it does not confer migration properties and therefore appears to induce a partial or incomplete EMT in HepG2 cells.

\section{Discussion}

In this study, we have shown that endosulfan transiently sensitizes HepG2 cells to anoikis, disrupts the epithelial phenotype of HepG2 and induces a partial EMT process.

Anoikis is defined as cell death induced by inappropriate or loss of cell adhesion (Frisch and Francis, 1994; Meredith et al., 1993). HepG2 carcinoma cells are resistant to anoikis but after endosulfan treatment we observed an induction of caspase-3 activity in poly-HEMA culture within the first $24 \mathrm{~h}$. After that, cells recovered their resistance to anoikis as shown by increased XIAP mRNA levels. This endogenous caspase inhibitor protein has been shown to contribute to the anoikis resistance of various carcinoma cells (Berezovskaya et al., 2005; Liu et al., 2006). Hence, overexpression of XIAP in cancer cells is linked to their increased resistance to apoptosis and the expression level reflects apoptosis sensitivity (Shi et al., 2008). Acquisition of anoikis resistance is a likely prerequisite for tumor cells to successfully metastasize to distant sites (Liotta and Kohn, 2004). The loss of cellular contact with the basement membrane constitutes the starting point of the onset of anoikis. This cell-ECM interaction is monitored by integrins that bind to diverse ECM molecules and respond by triggering an intracellular cascade via SRC and FAK kinases. We found that endosulfan increases the phosphorylation of FAK at the Tyr 925 residue, an event likely to contribute toward the activation of downstream signaling events including the Rho GTPase pathway. This sustained phosphorylation of FAK after endosulfan exposure correlated with the overexpression and relocalization of the cytoskeletal RhoGTPase proteins (data not shown) and their main effector ROCK1. This cascade has been linked to cancer cell migration/invasion during metastasis via the control of cytoskeletal remodeling (Yamazaki et al., 2005). FAK is a major protein of the focal adhesion complex that integrates signals from growth factors and integrins to control ECM interactions, migration and invasion (Mitra et al., 2005). This family of kinases was linked to tumor invasiveness and their expression and/or activation is frequently associated with metastatic tumors (Gabarra-Niecko et al., 2003; McLean et al., 2005). Notably, in parallel to FAK phosphorylation, we found an up-regulation of fibronectin, a major protein that serves as a scaffold for the fibrillar ECM. All these events occurred in parallel to a rearrangement of the F-actin cytoskeleton with formation of stress fibers in 
A

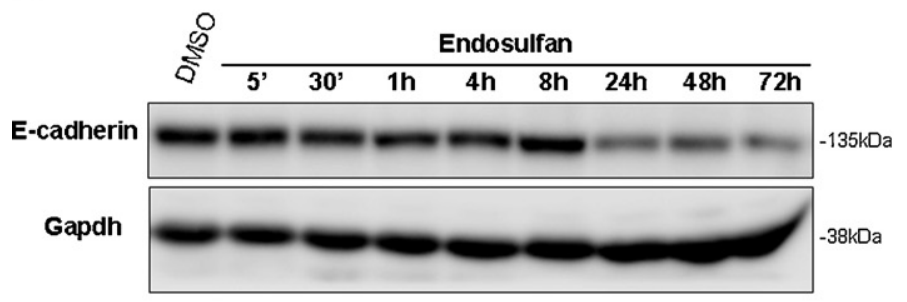

B

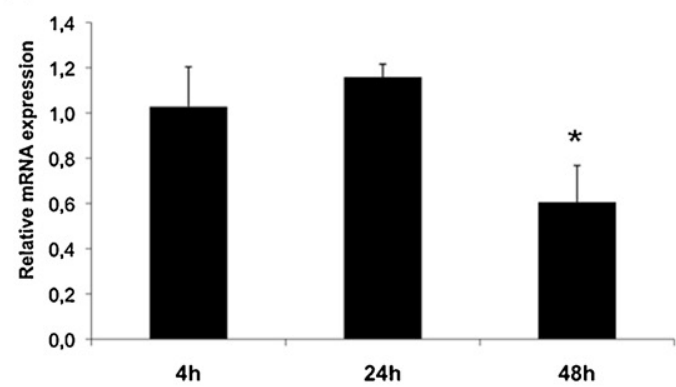

D
- SNAIL

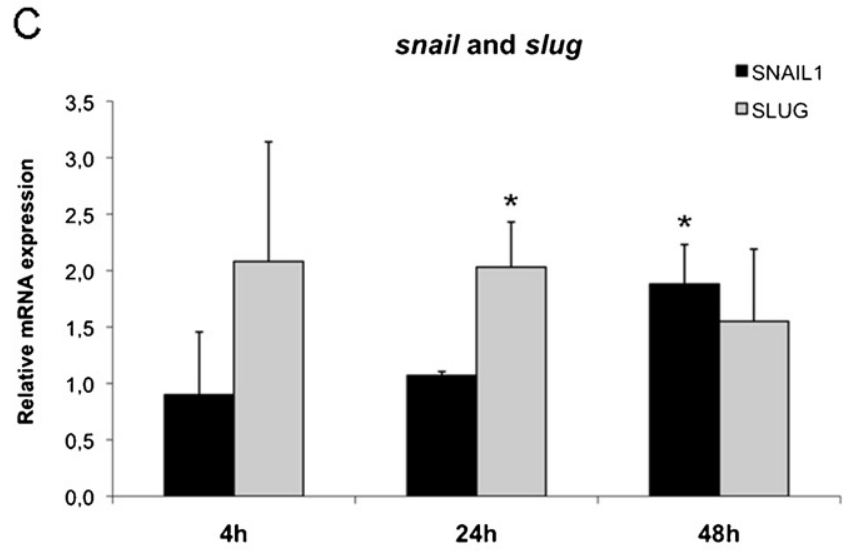

snail and slug

C
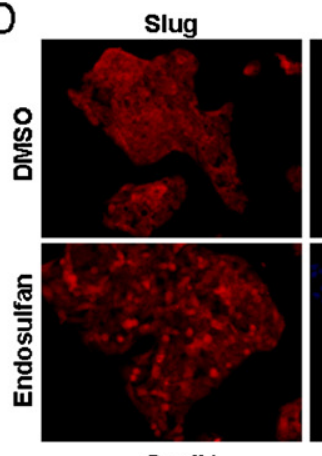

Snail1
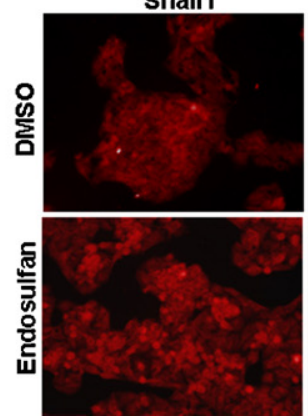

E-cadherin
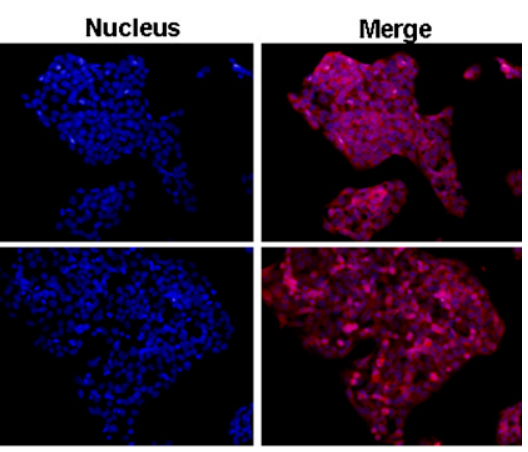

Nucleus
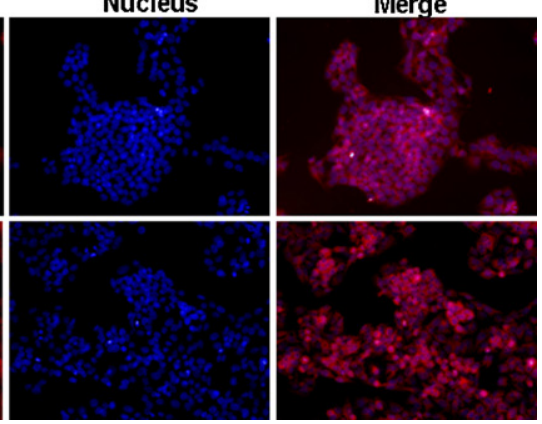

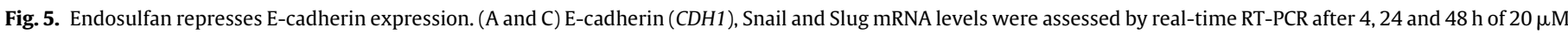

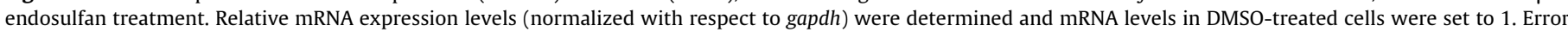

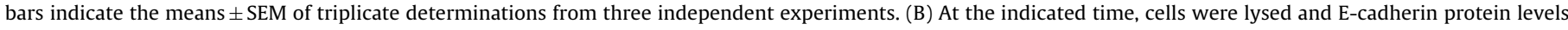

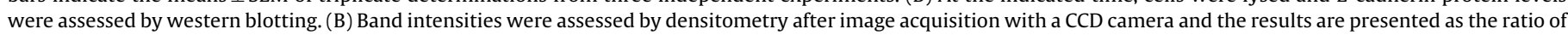

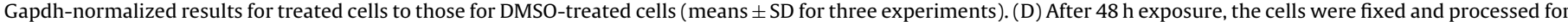

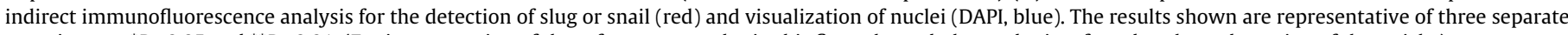
experiments. ${ }^{*} P<0.05$ and ${ }^{* *} P<0.01$. (For interpretation of the references to color in this figure legend, the reader is referred to the web version of the article.)

endosulfan-treated cells. This phenomenon has aleady been described during cellular stress and cell migration (Pollard and Borisy, 2003). Thus, endosulfan appears to structurally reorganize the cytoskeleton and to modify the ECM composition. These changes were accompanied by phenotypical modifications such as those observed during cell dedifferentiation (van Zijl et al., 2009a,b).

The EMT process has been shown to tightly correlate with anoikis resistance (Klymkowsky and Savagner, 2009; Smit et al., 2009). Genes that drive EMT (such as Snail, Slug, ZEB1/2, and Twist) frequently down-regulate E-cadherin and confer anoikis resistance. Indeed, it has been demonstrated that the loss of Ecadherin is a major landmark in the progression of EMT, and confers to epithelial cells a resistance to anoikis (Fouquet et al., 2004; Kumar et al., 2011). During EMT, loss of anchorage is a critical event required for cell migration (Yilmaz and Christofori, 2010). We observed a repression of E-cadherin from $24 \mathrm{~h}$ of endosulfan treatment, coinciding with the time at which the basal anoikis resistance status was observed. Consistently with these results, we found that endosulfan could both overexpress and activate the E-cadherin repressors Snail1 and Slug, two important factors for EMT induction (Polyak and Weinberg, 2009). The Snail family members are most widely recognized as suppressors of E-cadherin expression and regulate other aspects of the EMT phenotype, such as increased expression of fibronectin and protection from cell death (Zeisberg and Neilson, 2009). The disruption of E-cadherinmediated adhesion is thought to be a key step in the progression of hepatocarcinoma (Behrens, 1993; Takeichi, 1993; Christofori and Semb, 1999). Indeed, E-cadherin downregulation in HCC is associated with increased tumor size, low levels of histological differentiation, invasion recurrence, metastasis and poor prognosis (Kozyraki et al., 1996; Yang and Weinberg, 2008).

We also observed a stabilization of the $\beta$-catenin protein and its translocation to the nucleus in HepG2 cells treated with endosulfan. E-cadherin repression led to its disappearance from the intercellular junctions and to the release of $\beta$-catenin into the cytoplasm. The membrane-unbound $\beta$-catenin is usually phosphorylated by a complex responsible for its degradation through the ubiquitinproteasome system (Cowin et al., 2005; Peifer and Polakis, 2000). Docking of the Wnt ligand to its Frizzled (Fz) receptor triggers activation of the canonical Wnt pathway and allows $\beta$-catenin to accumulate in the cytoplasm and translocate to the nucleus. There it functions as a cofactor for members of the Tcf/Lef family of transcription factors, which further activate the transcription 
A

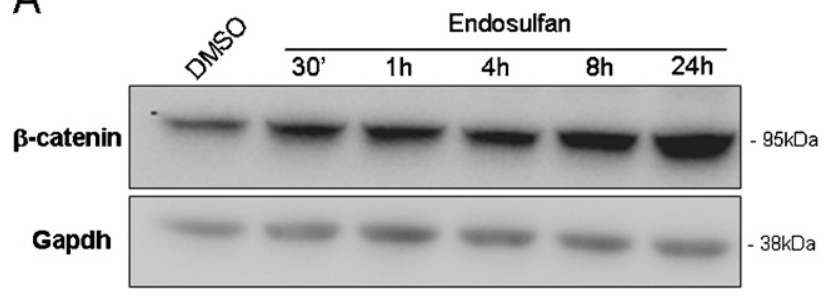

C
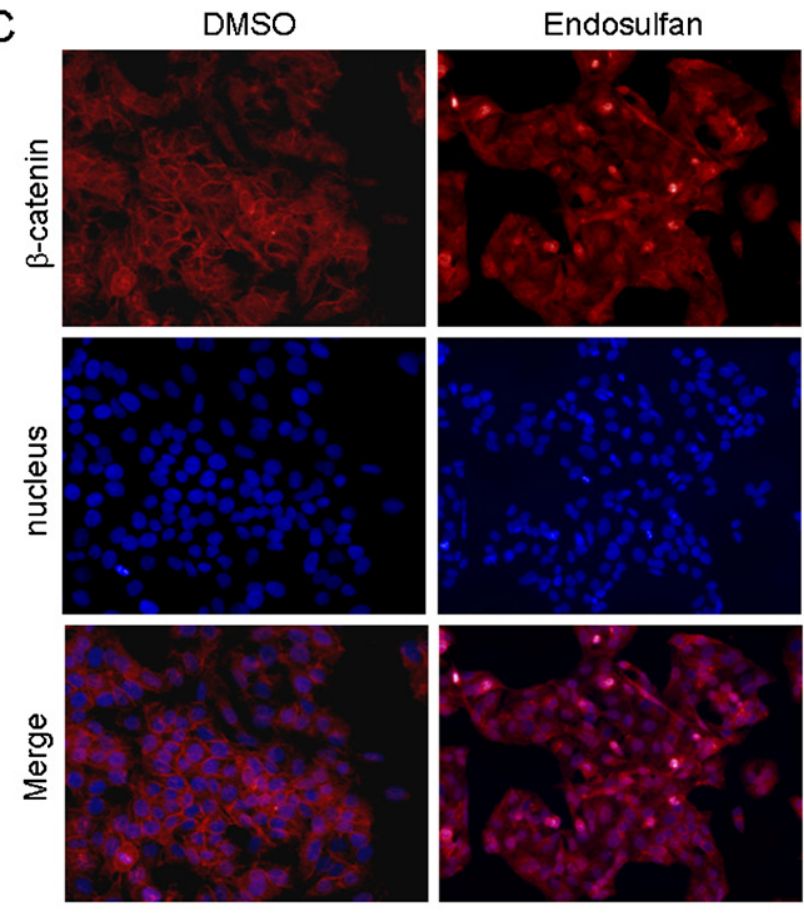

B

D

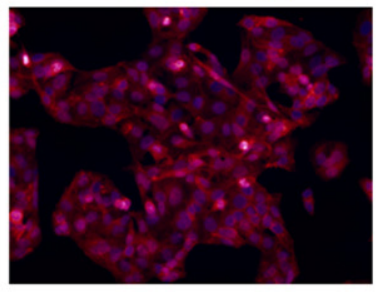

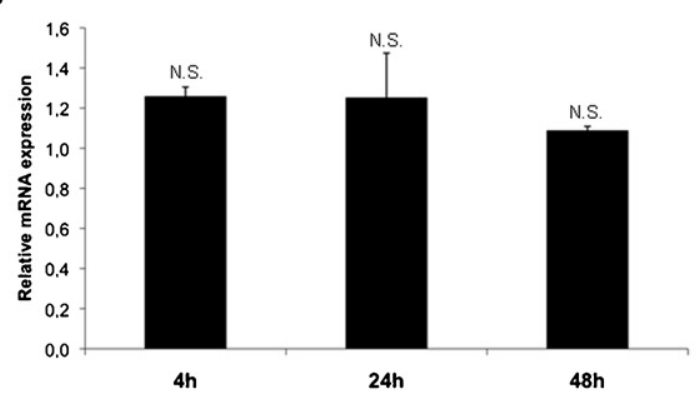

4h

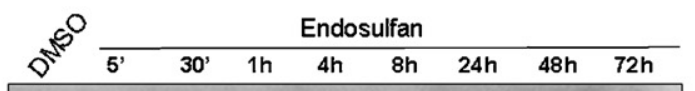

LEF1/TCF-1

Gapdh
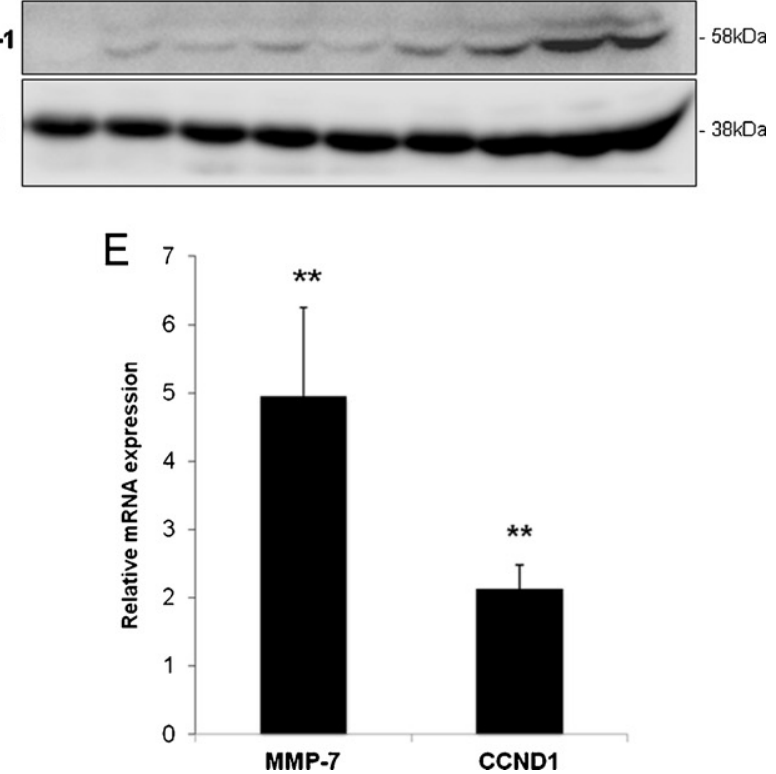

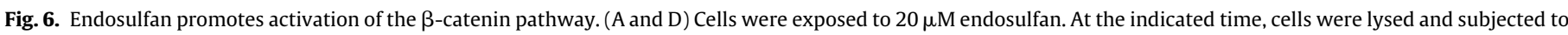

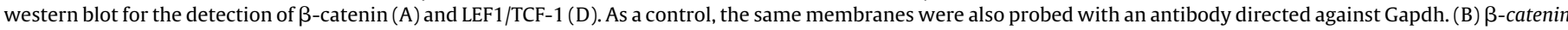

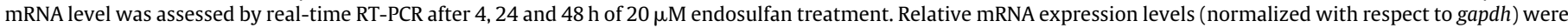

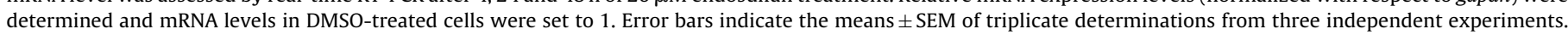

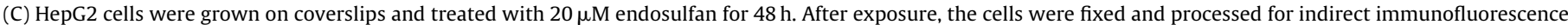

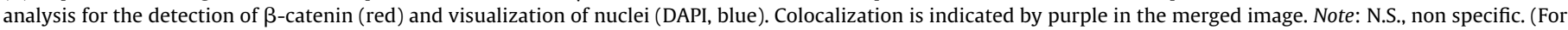
interpretation of the references to color in this figure legend, the reader is referred to the web version of the article.)

of important genes, such as TCF-1, MMP-7, S100a4 or fibronectin (Papkoff et al., 1996; Huber et al., 1996; Behrens et al., 1996; Yilmaz and Christofori, 2009). Increased levels of the gene CCND1 encoding the protein cyclin D1 is correlated with tumor progression and metastasis recurrence in HCC (Qin and Tang, 2004) and it is also used as a marker of fibrosis (Guarino et al., 2009). MMP-7 (matrix metallo-proteinase-7) and fibronectin are both proteins implicated in cancer cell invasion and metastasis (Gao et al., 2011; Bianchi et al., 2010). Concordantly, we found that the stabilization of $\beta$-catenin in the nucleus after endosulfan exposure was associated with the overexpression of S100a4, MMP-7, fibronectin and CCND1.

In addition to an increased expression of mesenchymal markers such as S100a4, MMP-7 and fibronectin, endosulfan also increased the expression of the most commonly used EMT biomarker vimentin. Though normally present in mesenchymal cells, vimentin may also be found in metastatic cells after EMT (Satelli and Li, 2011) or in epithelial cells in response to a cellular stress (Zeisberg et al., 2009).

We found that endosulfan induced an EMT-like event characterized by the loss of E-cadherin expression, modulation of the cytoskeletal architecture, synthesis of mesenchymal markers and resistance to anoikis. However, despite fulfilling all the required modifications, cells exposed to endosulfan failed to migrate. Many processes involving the transient loss of epithelial features without full acquisition of mesenchymal characteristics have been described as occurring both during development and in adult organisms (Grünert et al., 2003; Huber et al., 2005). Such a metastable phenotype can lead to the simultaneous expression of epithelial and mesenchymal markers. For example, E-cadherin, $\beta$-catenin, cytokeratin and vimentin co-expression has been described in edge cells during avian epiloby (Futterman et al., 2011). We found that endosulfan induced an EMT-like event that occurred without cell migration, as demonstrated by the inefficiency of this pesticide at accelerating wound closure in a HepG2 monolayer. Cell motility involves the integration of diverse biophysical processes including the dynamic formation and disruption of cell substratum attachments along with the extension of membrane protrusions. Notably, we observed that endosulfan increased the synthesis and the deposition of fibronectin in the extracellular medium. However, we observed no increase in the gene expression of the fibronectin receptor itga5. This gene mediates cell 
A

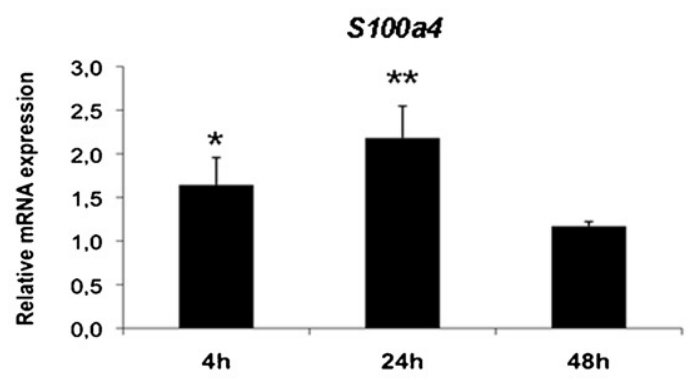

B
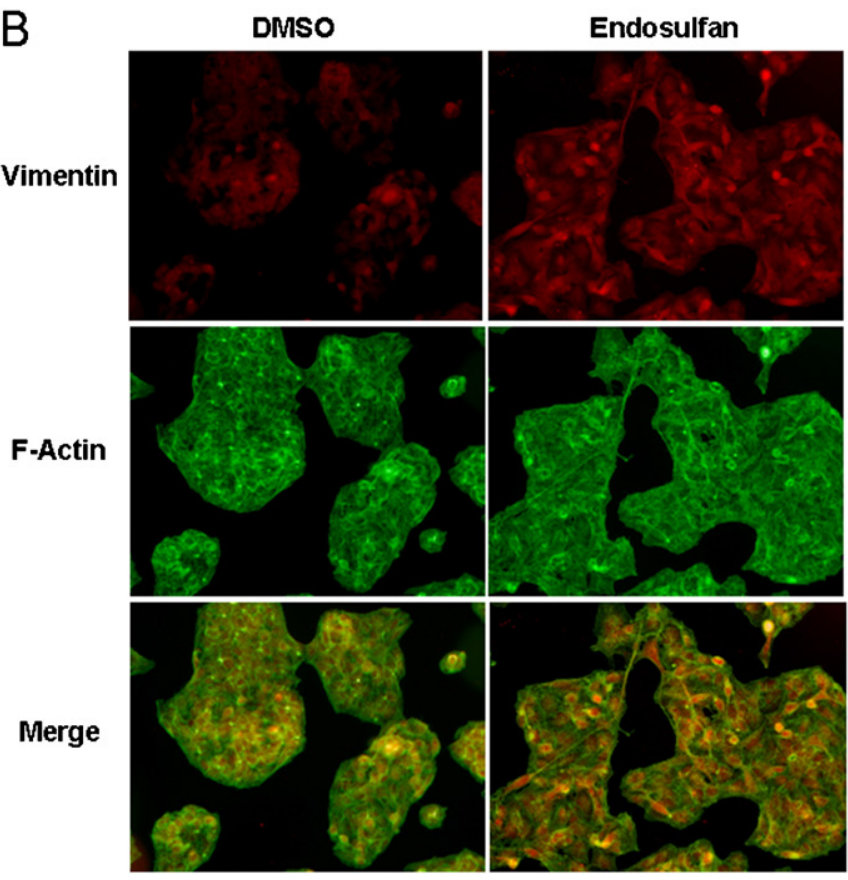

C

\section{Oh \\ $24 \mathrm{~h}$}

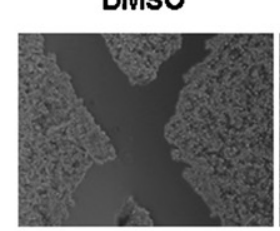

Endosulfan
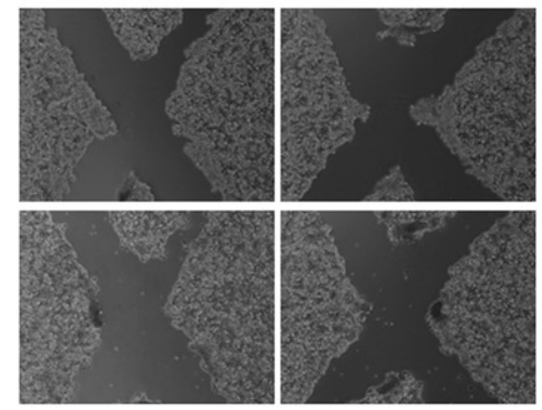

Oh
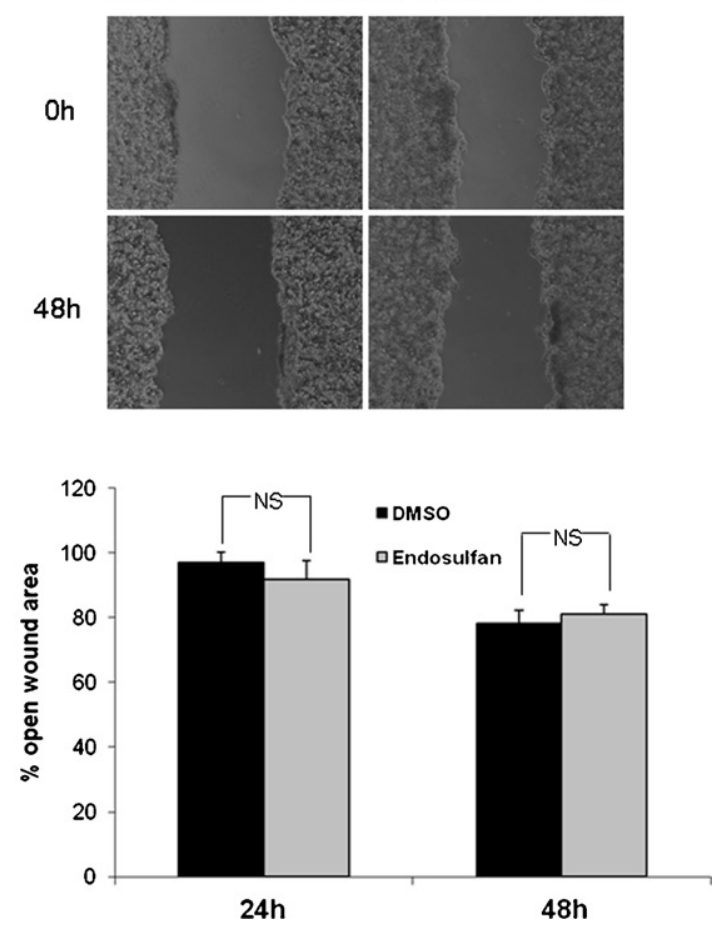

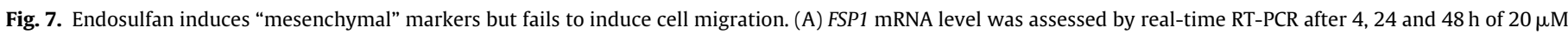

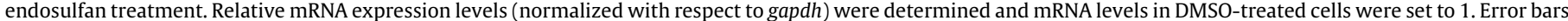

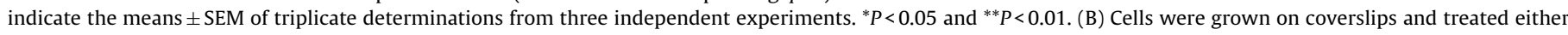

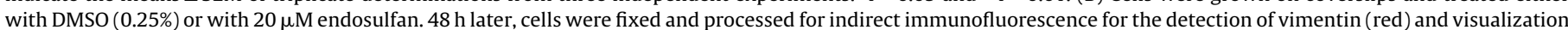

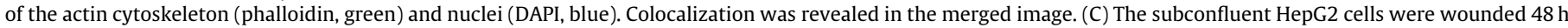

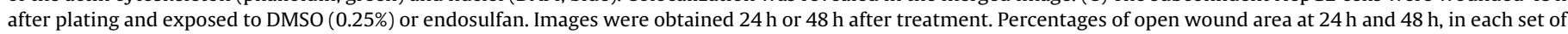

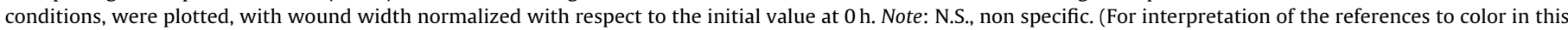
figure legend, the reader is referred to the web version of the article.)

adhesion and migration on fibronectin. One possible mechanism underlying this failure of the cells to migrate despite the observed endosulfan induced EMT-like phenotype, could be a change in the synthesis of basement membrane constituents. We hypothesized that this failure to migrate occurred due to inadequate ECM composition and attachment (Chiarugi and Giannoni, 2008). However, the use of collagen, fibronectin and poly-L-lysine coating (data not shown) failed to induce cell motility. Among other proteins, integrins play a key role in cell adhesion and migration processes. These heterodimeric membrane-spanning receptors are the drivers of cell migration allowing a physical linkage between the actin cytoskeleton and ECM (Vicente-Manzanares et al., 2009). We can suppose that disruption of integrin synthesis and/or signaling could account for the incapacity of endosulfan-exposed cells to migrate.

Finally, it has been demonstrated that endosulfan is mainly metabolized in human liver cells by cytochromes P450, 2B6 and $3 \mathrm{~A} 4$, two isoforms either not detectable or very weakly expressed in HepG2 cells (Casabar et al., 2006; Wilkening et al., 2003). This fact strongly suggests that in this study, the effects induced by endosulfan on EMT and anoikis could be attributed to the parent compound and not to its metabolite.

For the first time, we have highlighted the potential carcinogenic effect of endosulfan in vitro using EMT biomarkers also used in vivo on liver. We have shown that this organochlorine pesticide could induce both cellular and molecular changes, which could lead to liver damage and cancer aggravation.

\section{Conflict of interest}

The authors declare that they have no conflict of interests.

\section{Acknowledgments}

The authors received a Public Institutional Funding from INRA and the French National Research Agency (ANR "ONCOPOP" 06SEST26). We gratefully acknowledge R. Barouki and X. Coumoul for helpful scientific discussion. 


\section{References}

Aggarwal, M., Naraharisetti, S.B., Dandapat, S., Degen, G.H., Malik, J.K., 2008. Perturbations in immune responses induced by concurrent subchronic exposure to arsenic and endosulfan. Toxicology 251, 51-60.

Ahmed, T., Pathak, R., Mustafa, M.D., Kar, R., Tripathi, A.K., Ahmed, R.S., Banerjee, B.D., 2011. Ameliorating effect of $\mathrm{N}$-acetylcysteine and curcumin on pesticideinduced oxidative DNA damage in human peripheral blood mononuclear cells. Environ. Monit. Assess. 179, 293-299.

Antherieu, S., Ledirac, N., Luzy, A.P., Lenormand, P., Caron, J.C., Rahmani, R., 2007. Endosulfan decreases cell growth and apoptosis in human HaCaT keratinocytes: partial ROS-dependent ERK1/2 mechanism. J. Cell. Physiol. 213, 177-186.

Bajpayee, M., Pandey, A.K., Zaidi, S., Musarrat, J., Parmar, D., Mathur, N., Seth, P.K. Dhawan, A., 2006. DNA damage and mutagenicity induced by endosulfan and its metabolites. Environ. Mol. Mutagen. 47, 682-692.

Bedor, C.N., Morais, R.J., Cavalcanti, L.S., Ferreira, J.V., Pavão, A.C., 2010. Carcinogenic potential of endosulfan and its metabolites based on a quantum chemical model. Sci. Total Environ. 408, 6281-6284.

Behrens, J., 1993. The role of cell adhesion molecules in cancer invasion and metastasis. Breast Cancer Res. Treat. 24, 175-184.

Behrens, J., von Kries, J.P., Kühl, M., Bruhn, L., Wedlich, D., Grosschedl, R., Birchmeier, W., 1996. Functional interaction of beta-catenin with the transcription factor LEF-1. Nature 382, 638-642.

Berezovskaya, O., Schimmer, A.D., Glinskii, A.B., Pinilla, C., Hoffman, R.M., Reed, J.C., Glinsky, G.V., 2005. Increased expression of apoptosis inhibitor protein XIAP contributes to anoikis resistance of circulating human prostate cancer metastasis precursor cells. Cancer Res. 65, 2378-2386.

Bianchi, A., Gervasi, M.E., Bakin, A., 2010. Role of $\beta 5$-integrin in epithelial-mesenchymal transition in response to TGF- $\beta$. Cell Cycle 9, 1647-1659.

Brabletz, T., Jung, A., Dag, S., Hlubek, F., Kirchner, T., 1999. Beta-catenin regulates the expression of the matrix metalloproteinase-7 in human colorectal cancer. Am. J. Pathol. 155, 1033-1038.

Briz, V., Molina-Molina, J.M., Sánchez-Redondo, S., Fernández, M.F., Grimalt, J.O., Olea, N., Rodríguez-Farré, E., Suñol, C., 2011. Differential estrogenic effects of the persistent organochlorine pesticides dieldrin, endosulfan, and lindane in primary neuronal cultures. Toxicol. Sci. 120, 413-427.

Casabar, R.C., Wallace, A.D., Hodgson, E., Rose, R.L., 2006. Metabolism of endosulfanalpha by human liver microsomes and its utility as a simultaneous in vitro probe for CYP2B6 and CYP3A4. Drug Metab. Dispos. 34, 1779-1785.

Cavallaro, U., Christofori, G., 2004. Cell adhesion and signalling by cadherins and Ig-CAMs in cancer. Nat. Rev. Cancer 4, 118-132.

Chan, M.P., Morisawa, S., Nakayama, A., Kawamoto, Y., Yoneda, M., 2006. Development of an in vitro blood-brain barrier model to study the effects of endosulfan on the permeability of tight junctions and a comparative study of the cytotoxic effects of endosulfan on rat and human glial and neuronal cell cultures. Environ. Toxicol. 21, 223-235.

Chatzizacharias, N.A., Kouraklis, G.P., Theocharis, S.E., 2008. Clinical significance of FAK expression in human neoplasia. Histol. Histopathol. 23, 629-650.

Chiarugi, P., Giannoni, E., 2008. Anoikis: a necessary death program for anchoragedependent cells. Biochem. Pharmacol. 76, 1352-1364.

Choudhary, N., Sharma, M., Verma, P., Joshi, S.C., 2003. Hepato and nephrotoxicity in rat exposed to endosulfan. J. Environ. Biol. 24, 305-308.

Christofori, G., Semb, H., 1999. The role of the cell-adhesion molecule E-cadherin as a tumour-suppressor gene. Trends Biochem. Sci. 24, 73-76.

Cicchini, C., Laudadio, I., Citarella, F., Corazzari, M., Steindler, C., Conigliaro, A., Fantoni, A., Amicone, L., Tripodi, M., 2008. TGFbeta-induced EMT requires focal adhesion kinase (FAK) signaling. Exp. Cell Res. 314, 143-152.

Cowin, P., Rowlands, T.M., Hatsell, S.J., 2005. Cadherins and catenins in breast cancer. Curr. Opin. Cell Biol. 17, 499-508.

Deramaudt, T.B., Dujardin, D., Hamadi, A., Noulet, F., Kolli, K., De Mey, J., Takeda, K., Rondé, P., 2011. FAK phosphorylation at Tyr-925 regulates cross-talk between focal adhesion turnover and cell protrusion. Mol. Biol. Cell 22, 964-975.

Ehrlich, H.P., Sun, B., Saggers, G.C., Kromath, F., 2006. Gap junction communications influence upon fibroblast synthesis of type I collagen and fibronectin. J. Cell. Biochem. 98, 735-743.

Fautrel, A., Chesné, C., Guillouzo, A., de Sousa, G., Placidi, M., Rahmani, R., Braut, F., Pichon, J., Hoellinger, H., Vintézou, P., Diarte, I., Melcion, C., Cordier, A., Lorenzon, G., Benicourt, M., Vannier, B., Fournex, R., Peloux, A.F., Bichet, N., Gouy, D., Cano, J.P., Lounes, R., 1991. A multicentre study of acute in vitro cytotoxicity in rat liver cells. Toxicol. In Vitro 5, 543-547.

Fouquet, S., Lugo-Martínez, V.H., Chambaz, J., Cardot, P., Pinçon-Raymond, M., Thenet, S., 2004. Control of the survival/apoptosis balance by E-cadherin: role in enterocyte anoikis. J. Soc. Biol. 198, 379-383.

Fransson-Steen, R., Flodström, S., Wärngård, L., 1992. The insecticide endosulfan and its two stereoisomers promote the growth of altered hepatic foci in rats. Carcinogenesis 13, 2299-2303.

Fransvea, E., Angelotti, U., Antonaci, S., Giannelli, G., 2008. Blocking transforming growth factor-beta up-regulates E-cadherin and reduces migration and invasion of hepatocellular carcinoma cells. Hepatology 47, 1557-1566.

Frisch, S.M., Francis, H., 1994. Disruption of epithelial cell-matrix interactions induces apoptosis. J. Cell Biol. 124, 619-626.

Futterman, M.A., García, A.J., Zamir, E.A., 2011. Evidence for partial epithelial-tomesenchymal transition (pEMT) and recruitment of motile blastoderm edge cells during avian epiboly. Dev. Dyn. 240, 1502-1511.
Gabarra-Niecko, V., Schaller, M.D., Dunty, J.M., 2003. FAK regulates biological processes important for the pathogenesis of cancer. Cancer Metastasis Rev. 22, 359-374.

Gao, Q., Wang, X.Y., Qiu, S.J., Zhou, J., Shi, Y.H., Zhang, B.H., Fan, J., 2011. Tumor stroma reaction-related gene signature predicts clinical outcome in human hepatocellular carcinoma. Cancer Sci. 102, 1522-1531.

Gebäck, T., Schulz, M.M., Koumoutsakos, P., Detmar, M., 2009. TScratch: a novel and simple software tool for automated analysis of monolayer wound healing assays. Biotechniques 46, 265-274.

Grünert, S., Jechlinger, M., Beug, H., 2003. Diverse cellular and molecular mechanisms contribute to epithelial plasticity and metastasis. Nat. Rev. Mol. Cell Biol. 4, 657-665.

Guarino, M., Tosoni, A., Nebuloni, M., 2009. Direct contribution of epithelium to organ fibrosis: epithelial-mesenchymal transition. Hum. Pathol. 40, 1365-1376.

Hardell, L., Eriksson, M., 2003. Is the decline of the increasing incidence of nonHodgkin lymphoma in Sweden and other countries a result of cancer preventive measures? Environ. Health Perspect. 111, 1704-1706.

Hashizume, T., Yoshitomi, S., Asahi, S., Uematsu, R., Matsumura, S., Chatani, F., Oda, H., 2010. Advantages of human hepatocyte-derived transformants expressing a series of human cytochrome p450 isoforms for genotoxicity examination. Toxicol. Sci. 116, 488-497.

Huber, M.A., Kraut, N., Beug, H., 2005. Molecular requirements for epithelial-mesenchymal transition during tumor progression. Curr. Opin. Cell Biol. 17, 548-558.

Huber, O., Korn, R., McLaughlin, J., Ohsugi, M., Herrmann, B.G., Kemler, R., 1996. Nuclear localization of beta-catenin by interaction with transcription factor LEF1. Mech. Dev. 59, 3-10.

Høyer, A.P., Gerdes, A.M., Jørgensen, T., Rank, F., Hartvig, H.B., 2002. Organochlorines, p53 mutations in relation to breast cancer risk and survival. A Danish cohortnested case-controls study. Breast Cancer Res. Treat. 71, 59-65.

Iwai, S., Yonekawa, A., Harada, C., Hamada, M., Katagiri, W., Nakazawa, M., Yura, Y., 2010. Involvement of the Wnt- $\beta$-catenin pathway in invasion and migration of oral squamous carcinoma cells. Int. J. Oncol. 37, 1095-1103.

Jou, J., Diehl, A.M., 2010. Epithelial-mesenchymal transitions and hepatocarcinogenesis. J. Clin. Invest. 120, 1031-1034.

Kalluri, R., Weinberg, R.A., 2009. The basics of epithelial-mesenchymal transition. J. Clin. Invest. 119, 1420-1428.

Karatas, A.D., Aygun, D., Baydin, A., 2006. Characteristics of endosulfan poisoning: a study of 23 cases. Singapore Med. J. 47, 1030-1032.

Kim, H., Choi, G.H., Na, D.C., Ahn, E.Y., Kim, G.I., Lee, J.E., Cho, J.Y., Yoo, J.E., Choi, J.S., Park, Y.N., 2011. Human hepatocellular carcinomas with "Stemness"-related marker expression: keratin 19 expression and a poor prognosis. Hepatology 54, 1707-1717.

Klymkowsky, M.W., Savagner, P., 2009. Epithelial-mesenchymal transition: a cancer researcher's conceptual friend and foe. Am. J. Pathol. 174, 1588-1593.

Kozyraki, R., Scoazec, J.Y., Flejou, J.F., D’Errico, A., Bedossa, P., Terris, B., Fiorentino, M., Bringuier, A.F., Grigioni, W.F., Feldmann, G., 1996. Expression of cadherins and alpha-catenin in primary epithelial tumors of the liver. Gastroenterology 110, 1137-1149.

Kumar, S., Park, S.H., Cieply, B., Schupp, J., Killiam, E., Zhang, F., Rimm, D.L., Frisch, S.M., 2011. A pathway for the control of anoikis sensitivity by E-cadherin and epithelial-to-mesenchymal transition. Mol. Cell. Biol. 31, 4036-4051.

Li, D., Liu, J., Li, J., 2011. Genotoxic evaluation of the insecticide endosulfan based on the induced GADD153-GFP reporter gene expression. Environ. Monit. Assess. $176,251-258$

Liotta, L.A., Kohn, E., 2004. Anoikis: cancer and the homeless cell. Nature 430, 973-974.

Liu, Z., Li, H., Wu, X., Yoo, B.H., Yan, S.R., Stadnyk, A.W., Sasazuki, T., Shirasawa, S., LaCasse, E.C., Korneluk, R.G., Rosen, K.V., 2006. Detachment-induced upregulation of XIAP and cIAP2 delays anoikis of intestinal epithelial cells. Oncogene 25, 7680-7690.

Lopez-Espinosa, M.J., Lopez-Navarrete, E., Rivas, A., Fernandez, M.F., Nogueras, M. Campoy, C., Olea-Serrano, F., Lardelli, P., Olea, N., 2008. Organochlorine pesticide exposure in children living in southern Spain. Environ. Res. 106, 1-6.

Matsuo, N., Shiraha, H., Fujikawa, T., Takaoka, N., Ueda, N., Tanaka, S., Nishina, S., Nakanishi, Y., Uemura, M., Takaki, A., Nakamura, S., Kobayashi, Y., Nouso, K., Yagi, T., Yamamoto, K., 2009. Twist expression promotes migration and invasion in hepatocellular carcinoma. BMC Cancer 9, 240.

McLean, G.W., Carragher, N.O., Avizienyte, E., Evans, J., Brunton, V.G., Frame, M.C. 2005. The role of focal-adhesion kinase in cancer - a new therapeutic opportunity. Nat. Rev. Cancer 5, 505-515.

Medici, D., Hay, E.D., Olsen, B.R., 2008. Snail and Slug promote epithelial-mesenchymal transition through beta-catenin-T-cell factor-4dependent expression of transforming growth factor-beta3. Mol. Biol. Cell 19, 4875-4887.

Meredith, J.E., Fazeli, B., Schwartz, M.A., 1993. The extracellular matrix as a cell survival factor. Mol. Biol. Cell 4, 953-961.

Merhi, M., Demur, C., Racaud-Sultan, C., Bertrand, J., Canlet, C., Estrada, F.B., GametPayrastre, L., 2010. Gender-linked haematopoietic and metabolic disturbances induced by a pesticide mixture administered at low dose to mice. Toxicology 267, 80-90.

Mitra, S.K., Hanson, D.A., Schlaepfer, D.D., 2005. Focal adhesion kinase: in command and control of cell motility. Nat. Rev. Mol. Cell Biol. 6, 56-68.

Moses, V., Peter, J.V., 2010. Acute intentional toxicity: endosulfan and other organochlorines. Clin. Toxicol. (Phila.) 48, 539-544. 
Ogunwobi, O.O., Liu, C., 2011. Therapeutic and prognostic importance of epithelial-mesenchymal transition in liver cancers: insights from experimental models. Crit. Rev. Oncol. Hematol.

Papkoff, J., Rubinfeld, B., Schryver, B., Polakis, P., 1996. Wnt-1 regulates free pools of catenins and stabilizes APC-catenin complexes. Mol. Cell. Biol. 16, 2128-2134.

Peifer, M., Polakis, P., 2000. Wnt signaling in oncogenesis and embryogenesis - a look outside the nucleus. Science 287, 1606-1609.

Peinado, H., Olmeda, D., Cano, A., 2007. Snail, Zeb and bHLH factors in tumour progression: an alliance against the epithelial phenotype? Nat. Rev. Cancer 7, 415-428.

Peinado, H., Portillo, F., Cano, A., 2004. Transcriptional regulation of cadherins during development and carcinogenesis. Int. J. Dev. Biol. 48, 365-375.

Perez-Carreon, J.I., Dargent, C., Merhi, M., Fattel-Fazenda, S., Arce-Popoca, E., VillaTreviño, S., Rouimi, P., 2009. Tumor promoting and co-carcinogenic effects in medium-term rat hepatocarcinogenesis are not modified by co-administration of 12 pesticides in mixture at acceptable daily intake. Food Chem. Toxicol. 47, 540-546.

Pollard, T.D., Borisy, G.G., 2003. Cellular motility driven by assembly and disassembly of actin filaments. Cell 112, 453-465.

Polyak, K., Weinberg, R.A., 2009. Transitions between epithelial and mesenchymal states: acquisition of malignant and stem cell traits. Nat. Rev. Cancer 9, 265-273.

Qin, L.X., Tang, Z.Y., 2004. Recent progress in predictive biomarkers for metastatic recurrence of human hepatocellular carcinoma: a review of the literature. J. Cancer Res. Clin. Oncol. 130, 497-513.

Riento, K., Ridley, A.J., 2003. Rocks: multifunctional kinases in cell behaviour. Nat. Rev. Mol. Cell Biol. 4, 446-456.

Roe, A.L., Snawder, J.E., Benson, R.W., Roberts, D.W., Casciano, D.A., 1993. HepG2 cells: an in vitro model for P450-dependent metabolism of acetaminophen. Biochem. Biophys. Res. Commun. 190, 15-19.

Roose, J., Clevers, H., 1999. TCF transcription factors: molecular switches in carcinogenesis. Biochim. Biophys. Acta 1424, M23-M37.

Ruch, R.J., Fransson, R., Flodstrom, S., Warngard, L., Klaunig, J.E., 1990. Inhibition of hepatocyte gap junctional intercellular communication by endosulfan, chlordane and heptachlor. Carcinogenesis 11, 1097-1101.

Satelli, A., Li, S., 2011. Vimentin in cancer and its potential as a molecular target for cancer therapy. Cell. Mol. Life Sci. 68, 3033-3046.

Schaller, M.D., 2010. Cellular functions of FAK kinases: insight into molecular mechanisms and novel functions. J. Cell Sci. 123, 1007-1013.

Shi, Y.H., Ding, W.X., Zhou, J., He, J.Y., Xu, Y., Gambotto, A.A., Rabinowich, H., Fan, J., Yin, X.M., 2008. Expression of X-linked inhibitor-of-apoptosis protein in hepatocellular carcinoma promotes metastasis and tumor recurrence. Hepatology 48, 497-507.

Silva, M.H., Gammon, D., 2009. An assessment of the developmental, reproductive and neurotoxicity of endosulfan. Birth Defects Res. B: Dev. Reprod. Toxicol. 86, $1-28$.

Smit, M.A., Geiger, T.R., Song, J.Y., Gitelman, I., Peeper, D.S., 2009. A Twist-Snail axis critical for TrkB-induced epithelial-mesenchymal transition-like transformation, anoikis resistance, and metastasis. Mol. Cell. Biol. 29, 3722-3737.

Takeichi, M., 1993. Cadherins in cancer: implications for invasion and metastasis. Curr. Opin. Cell Biol. 5, 806-811.

Tetsu, O., McCormick, F., 1999. Beta-catenin regulates expression of cyclin D1 in colon carcinoma cells. Nature 398, 422-426.

Trosko, J.E., 2011. The gap junction as a "Biological Rosetta Stone": implications of evolution, stem cells to homeostatic regulation of health and disease in the Barker hypothesis. J. Cell Commun. Signal. 5, 53-66.

van Zijl, F., Mair, M., Csiszar, A., Schneller, D., Zulehner, G., Huber, H., Eferl, R., Beug, H. Dolznig, H., Mikulits, W., 2009. Hepatic tumor-stroma crosstalk guides epithelial to mesenchymal transition at the tumor edge. Oncogene 28, 4022-4033.

van Zijl, F., Zulehner, G., Petz, M., Schneller, D., Kornauth, C., Hau, M., Machat, G. Grubinger, M., Huber, H., Mikulits, W., 2009. Epithelial-mesenchymal transition in hepatocellular carcinoma. Future Oncol. 5, 1169-1179.

Vicente-Manzanares, M., Choi, C.K., Horwitz, A.R., 2009. Integrins in cell migration - the actin connection. J. Cell Sci. 122, 199-206.

Weber, J., Halsall, C.J., Muir, D., Teixeira, C., Small, J., Solomon, K., Hermanson, M. Hung, H., Bidleman, T., 2010. Endosulfan, a global pesticide: a review of its fate in the environment and occurrence in the Arctic. Sci. Total Environ. 408, 2966-2984.

Wielenga, V.J., Smits, R., Korinek, V., Smit, L., Kielman, M., Fodde, R., Clevers, H., Pals, S.T., 1999. Expression of CD44 in Apc and Tcf mutant mice implies regulation by the WNT pathway. Am. J. Pathol. 154, 515-523.

Wilkening, S., Stahl, F., Bader, A., 2003. Comparison of primary human hepatocytes and hepatoma cell line Hepg2 with regard to their biotransformation properties. Drug Metab. Dispos. 31, 1035-1042.

Yamazaki, D., Kurisu, S., Takenawa, T., 2005. Regulation of cancer cell motility through actin reorganization. Cancer Sci. 96, 379-386.

Yang, J., Weinberg, R.A., 2008. Epithelial-mesenchymal transition: at the crossroads of development and tumor metastasis. Dev. Cell 14, 818-829.

Yilmaz, M., Christofori, G., 2009. EMT, the cytoskeleton, and cancer cell invasion. Cancer Metastasis Rev. 28, 15-33.

Zeisberg, M., Neilson, E.G., 2009. Biomarkers for epithelial-mesenchymal transitions. J. Clin. Invest. 119, 1429-1437. 